Portland State University

PDXScholar

9-16-2020

\title{
Transitioning into Conventional Housing: Narratives of Houseless Individuals
}

Joyce La Belle McNair

Portland State University

Follow this and additional works at: https://pdxscholar.library.pdx.edu/open_access_etds

Part of the Sociology Commons

Let us know how access to this document benefits you.

\section{Recommended Citation}

McNair, Joyce La Belle, "Transitioning into Conventional Housing: Narratives of Houseless Individuals" (2020). Dissertations and Theses. Paper 5572.

https://doi.org/10.15760/etd.7446

This Thesis is brought to you for free and open access. It has been accepted for inclusion in Dissertations and Theses by an authorized administrator of PDXScholar. Please contact us if we can make this document more accessible: pdxscholar@pdx.edu. 


\title{
Transitioning into Conventional Housing:
}

Narratives of Houseless Individuals

by

Joyce LaBelle McNair

A thesis submitted in partial fulfillment of the requirements for the degree of

\author{
Master of Science \\ in \\ Sociology
}

Thesis Committee: Veronica Dujon, Chair

Amy Lubitow

Alma Trinidad

\section{Portland State University}

2020 
(C) 2020 Joyce LaBelle McNair 


\begin{abstract}
\end{abstract}
Past research has shown that it is possible for individuals to exit houselessness. However, it does little to provide insights into the types of experiences and events that facilitate these moves towards housing stability. This study explores in-depth interviews, utilizing an interview guide with 12 individuals who exited houselessness in Portland, Oregon. This research project seeks to understand the conditions that influence successful exits out of houselessness from the perspective of the lived experiences of once houseless individuals. This study utilizes two theoretical frameworks, the theory of Habitus (Bourdieu, 1977 \& Wacquant, 1998) and the networking theory of Strong and Weak Ties (Granovetter, 1973), as the conceptual underpinning of this work. Habitus is the totality of one's resources which include social capital, (i.e., education, social class, and networks) economic capital (i.e.money and wealth), it is the totality of acquired experiences, and is expanded by day-to-day interactions. Through the utility of Habitus individuals learn how to maneuver in and out of houselessness. Granovetter's work also focuses on the value of social interactions. According to Granovetter, one's extended social network serves as an informational storehouse where knowledge is gained and transferred. These extended networks may prove to be ways in which individuals learn about services and programs that aid in houseless exits. Although both theories are somewhat dated, they are relevant for this study of individuals who have transitioned into housing stability. This study employs these theoretical frameworks to explore the social factors and conditions that enable houseless individuals to make the transition. It relies on narratives developed from interviews with 12 formerly houseless individuals and a grounded theoretical approach to uncover the processes, connections, and conditions that facilitate 
transitions out of houselessness. These conditions include access to institutional support that was provided from a variety of entry points ranging from contact with the criminal justice system, drug and alcohol programs, social service agencies; and access to social network supports that was facilitated primarily via family, friends, and acquaintances that leverage social capital. This study builds on previous research on houseless individuals who have integrated into conventional housing and lays the framework for future research on factors which facilitate such exits. 


\section{DEDICATION}

This thesis is dedicated to my family, friends, and everyone who has given me support, guidance, and encouragement throughout this amazing journey. To my Sister Sarah you walked this journey with me and I am so grateful for the incredible friendship and love that we share. To my Father Edward L. McNair and Mother Flora B. McNair (she left this life too soon) - I hope that I have made you proud! I am so grateful that you taught me that there is a God out there, and that She loves me more than I can imagine, and that all things are possible. Thank you, for never giving up on me, and for always being there for me. To my siblings (Edward, Robin, Marty, Nathan, Sarah, and Gabriel) - Our daily chats mean so much to me, I am so grateful to all of you, it is wonderful knowing that we all love and support one another, it gives me great comfort. To Sasha Bassett - who never stopped believing in me and kept me focused and helped me finish my thesis, I will never forget our time in graduate school I will miss our breakfast meetings. To my inspiration, Neal Panchamatia, - who motivated me to finish when I had decided to forget about it and move on. To Stacey Watson - who helped me recover from my auto accident and the death of my mother, you gently reminded me that I must complete my thesis. I am so grateful to you for your help. David McCarthy your assistance enabled me to reach and achieve a goal having disabilities made difficult, I love you. To Alyissia Wincher - who pushed me and insisted that I finish my thesis, you made me remember my goal and I am eternally grateful to you, and for your friendship. To Donna Marks there were times I wanted to quit graduate school and you reminded this is a small step in my journey which encouraged me to look at the big picture. Wyndham McNair, your help was invaluable, and without it none of this would be possible. Lastly, to my Three sons David, Shannon, and Edward - you are the reason I pursued my education-you are extraordinary, and I am so blessed to be your mother, you give me hope for tomorrow, and happiness for today, and I will always love you. Always believe in yourselves my sons, you are all bright and capable of achieving greatness! This degree is only a stepping stone to my PhD. and I am going to be Dr. Joyce Labelle McNair in the near future! 


\section{ACKNOWLEDGEMENTS}

I am grateful to God that She allowed me the opportunity to become houseless, that experience changed my life, from then on, I truly knew that She would never leave me nor forsake me.

I want to give special thanks to my thesis committee, Dr. Veronica Dujon (Chair), you have been a phenomenal support, I could not have completed my thesis without your encouragement thank you so much

Dr. Amy Lubitow, and Dr. Alma Trinidad for your phenomenal leadership encouragement guidance, and support. Dr. Sara Deboy, your timing saved the day, I appreciate your assistance, patience, and kindness. Dr. Dujon I will never forget your commitment to remain my chair even though you left the university, I could not have completed this process without your commitment and patience while I settled my life and returned to complete my thesis.

Lastly, to my participants in this study, I am so grateful for your willingness to share your experiences in exiting houselessness. I pray that you will continue to bless others and encourage them in believing that there is an end to houselessness and it begins with them. Blessings to you. 


\section{TABLE OF CONTENTS}

ABSTRACT

1.1 The New Population of Houseless Individuals .............................................4

1.2 Oregon and the Statistics on Houselessness for 2017 ..................................5

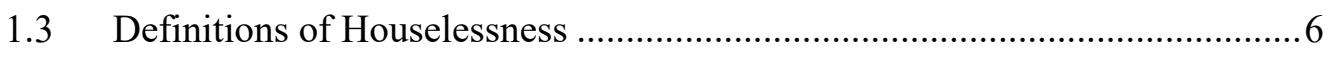

1.4 Homeless - Houseless........................................................................ 7

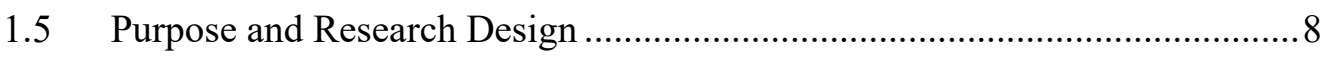

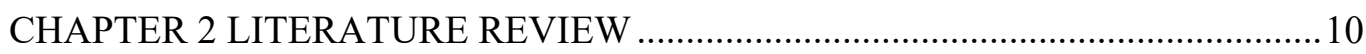

2.1 Major Causes of Houselessness ................................................................. 10

2.2 Impact of Social Networks, Friends, Family, and Associations ...................12

2.3 Social Service Agencies and Supportive Networks .................................... 15

2.4 Subjective Well-Being and Happiness ....................................................... 17

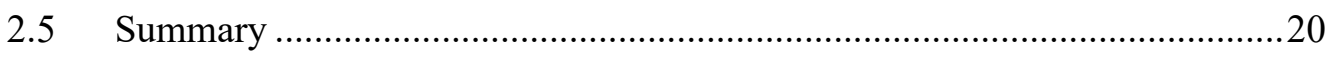

CHAPTER 3 THEORETICAL FRAMEWORK .....................................................22

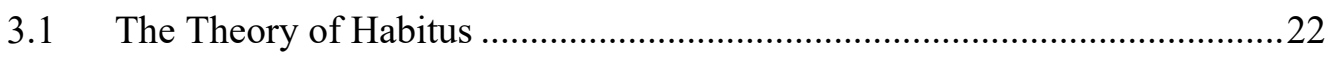

3.2 The Utility of Habitus to the Houseless .....................................................24

3.3 The Networking Theory of Strength of Weak Ties.....................................25

3.4 The Utility of The Strength of Weak Ties.................................................25

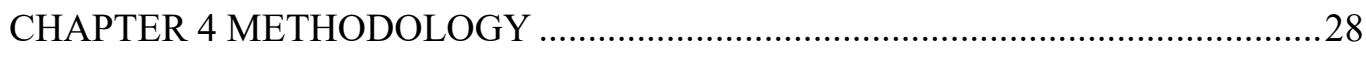

4.1 Participant Selection and Recruitment ...................................................29

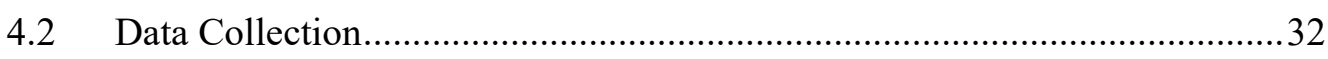

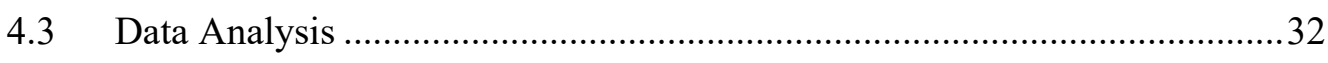

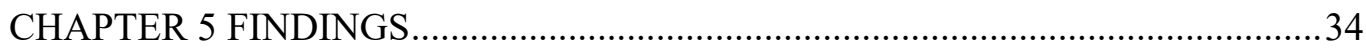

5.1 Demographic Participant Information Table............................................... 34

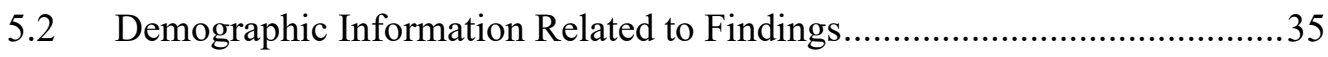

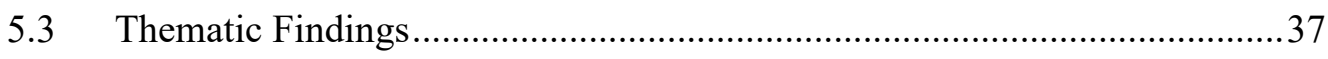

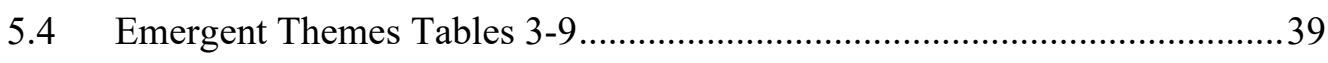


5.4.1 My Mind's Made Up .........................................................................40

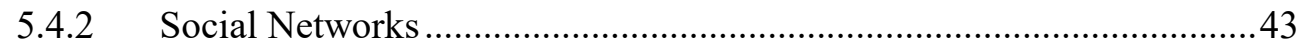

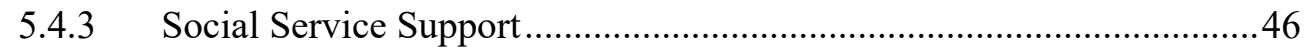

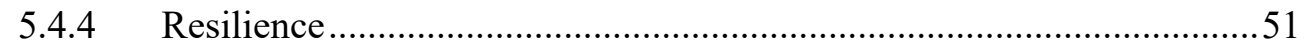

5.4.5 Feelings of Achieving Housing Stability ...............................................54

5.4.6 Change in Social Networks.................................................................

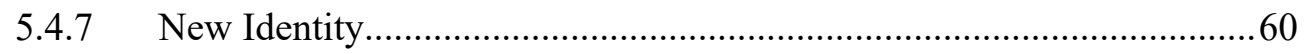

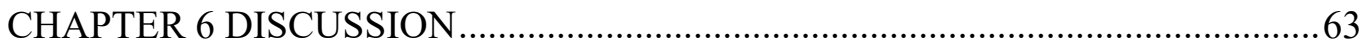

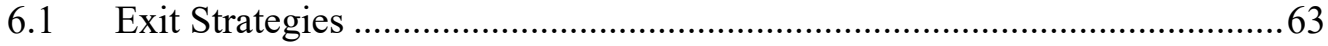

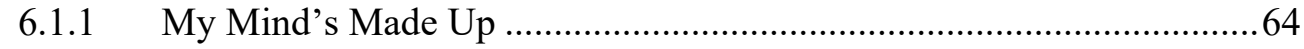

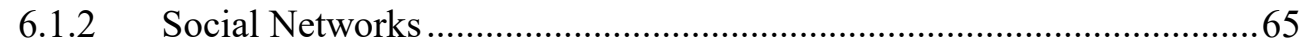

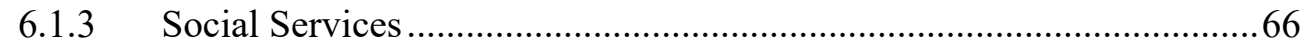

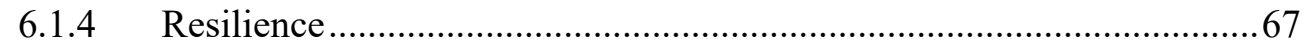

6.1.5 Feelings of Achieving Housing Stability ………………........................68

6.1.6 Changes in Social Networks …………………………………….....68

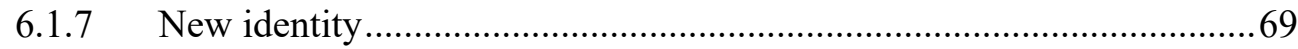

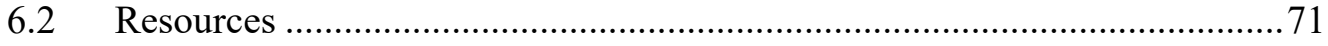

6.2.1 Personal Networks ……………………………………………....

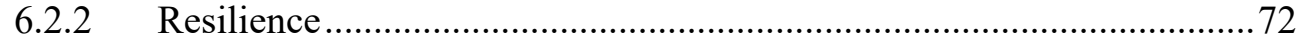

6.2.3 Social Networks Post Transition......................................................... 72

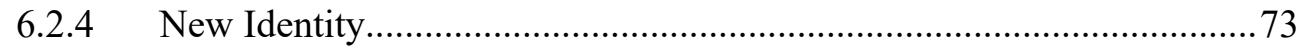

CHAPTER 7 REFLECTION AND CONCLUSION …………………………........74

7.1 Racial Disparities in Houseless Individuals ..................................................75

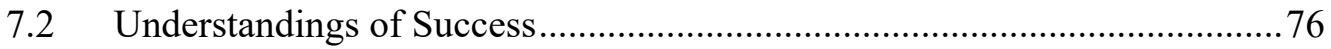

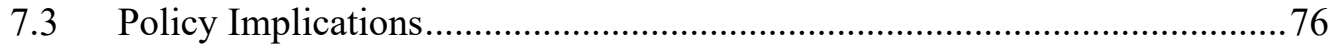

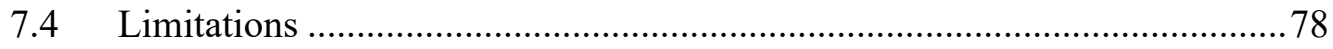

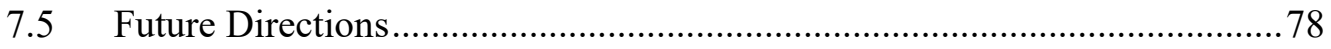

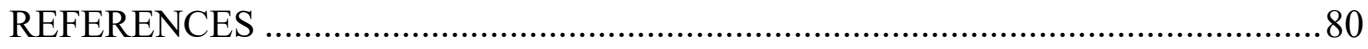

APPENDIX A: SAMPLE INTERVIEW GUIDE ………………………………........ 89

APPENDIX B: INFORMED CONSENT ……………………………………......99

APPENDIX C: OPENING STATEMENT ………………………………………..91

APPENDIX D: OPENING STATEMENT ………………………………………....92

APPENDIX E FREE OR FEE BASED COUNSELLING SERVICES IN

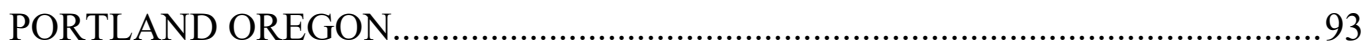




\section{LIST OF TABLES}

Table No.

Title

Page

1 Participant Demographic Information

2 Emergent Themes

$3 \quad$ My Mind's Made Up

42

$4 \quad$ Social Networks

45

$5 \quad$ Social Service Agency

50

$6 \quad$ Resilience

53

$7 \quad$ Feelings of Achieving Housing Stability

8 Change in Social Networks

59

$9 \quad$ New Identity 


\section{LIST OF FIGURES}

Figure No.

1 Conceptual Framework for Transition
Page

70 


\section{PREFACE}

In 1987, I became pregnant with my third son in a tumultuous and sometimes violent marriage. One day my husband walked away from us as if we never existed. I was alone, 25 years old and pregnant with our third child. I was grateful that my husband was in the military and took a degree of solace in his departure knowing that I could rely on the VA for assistance. That came to a screeching halt the day military officers knocked on my door in search of my soon to be ex-husband. I felt as if my whole world was crumbling underneath my feet. I felt as if God had abandoned me.Yet, something inside me shook; it was the fight or flight instinct kicking in. I had to keep on, if for no other reason than my children. Out of the trauma emerged a resilience that to this day makes me tearful. I started working temporary jobs, found a daycare for my children. I discovered that I was able to sustain my household financially while I was pregnant; however, as my belly grew I began to wonder how I would pay my bills and maintain my household while I recovered from childbirth.

I made an appointment with my landlord and explained the situation and asked if I could make arrangements to pay a higher rent to cover for the months I was unable to work. The landlord informed me that if I did not pay my rent, the managing company would start the eviction process. I remember walking back to my apartment in a daze wondering how I was going to have my baby, pack my belongings in storage and move myself and my children into my car. I don't know how I managed to care for them that night. I do not remember going to work the next day. The only thing I remember was arriving at the daycare to pick up my children and beginning to cry. Rosie, the woman who owned the daycare, attempted to console me to no avail. I tried to convey my situation, through my sobbing tears, Finally, I told her that I was going to become 
homeless the month I delivered my baby. She told me that I could stay in her back room of the daycare. Rosie, was planning on making it a nursery out of the space and said my children and I could stay there until I recovered and saved enough money to get a place for me and my children to live.

I will never forget that feeling, the day I moved into my own apartment. I felt safe, secure, happy, and in that moment, I felt invincible.

It is with great passion I pursue this research study. My experience with houselessness made me curious; I wondered how other individuals returned to conventional housing. I wanted to know if my path out of houselessness was unique. I wondered if others felt the excitement the day they received their keys to their own home.

In 1987, there were no programs that assisted houseless individuals, who desired to return to conventional housing, to my knowledge. I wondered how someone without any assistance could return to housing stability on their merit. I believe that my personal experience of overcoming houselessness allows me a vantage point that will be added an value to my study. My experience being houseless brings empathy to participants they will be respected and treated as human beings not as research subjects. In this way our shared experiences may invoke deep rich insights into the pathways out of houselessness.

While I was houseless, the person who was the most influential in my integration into mainstream society was the woman who owned the daycare that my children attended. Through my experiences with houselessness I have first-hand knowledge of how nonkin relationships quickly become a surrogate family. In that way, Rosie was not only my family, but she also was my Redeemer, and I could not have returned to housing stability without her assistance, and I will always be grateful to her. 


\section{CHAPTER 1 \\ INTRODUCTION}

Portland, Oregon represents a unique setting for the study of houselessness. It is home to one of the largest and most visible houseless populations in the nation.

It is known as a "Houseless Friendly State." Since, Oregon has this reputation other states such as Hawaii and Utah offer one-way free transportation to Portland Oregon. Thereby, reducing their states houseless populations and increasing the homeless population in Oregon (Blake, 2013). Literature suggests pathways out of houselessness are shaped and influenced by social support agencies, personal networks, employment opportunities, and the availability of affordable housing (Kidd et al. 2013; Maycock, O'Sullivan, and Corr 2011; Nova et al. 2008). Past research has shown that it is possible for individuals to exit houselessness. However, literature is limited and does little to provide insight into the types of experiences and events that facilitate the move towards housing stability. This study explores individual narrative accounts of 12 individuals who exited houselessness in Portland, Oregon.

It is the endeavor of this study to gain a deeper understanding through the utilization of a grounded theoretical approach to uncover the processes, connections, and conditions that facilitate transitions out of houselessness. This study adds to existing scholarship by providing an in-depth probe into the lived experiences and pathways out of houselessness as told from the prospective of previously houseless individuals residing in Portland, Oregon.

The research seeks to explore the pathways and experiences as individuals exit. It probes into agencies that facilitated such exits as told from the lived experiences of 12 individuals. 
To gain an informed understanding of how individuals, exit houselessness this study asks the following questions:

1. What social factors and experiences, as reported by research participants, influence their ability to move into conventional housing?

2. What are the resources and support services used by those who successfully transition into conventional housing?

Conducting qualitative research in this setting may yield insight into the pathways that supplement the efforts of service providers and aid individuals in houseless exits (Schmock Consulting, 2015; Mayock et al. 2011).

\subsection{The New Population of Houseless Individuals}

In the late 1950 's the population of houseless individuals was dominantly comprised of single adult men often referred to as hoboes and skid-row bums often, classified as lazy, vagrant, and stigmatized as social outcasts. Popular belief at the time was that these individuals opted for a carefree life rather than becoming a productive member of society (Burt, \& Cohen, 1989).

In 2016, the population of houseless individuals has become far more diverse, and included in this population are families, women, young adults, children, and the elderly (Anderson \& Rayens, 2004; La Gory, Fitzpatrick, \& Ritchey, 2001; Pescosolido \& Rubin, 2000). According to The National Law Center on Homelessness and Poverty, there are approximately 2.5 to 3.5 million Americans sleeping in shelters, transitional housing, and places not meant for human occupancy. What is alarming about this number is that there was an estimated 7.4 million Americans lost their homes in the economic downturn of 2009. 
Finally, according to the National Alliance to End Homelessness, racial minorities experience houselessness at rates disproportionate to their representation. More than 40 percent of all houseless individuals are Afro American, yet their representative percentage within the general population is $13 \%$. Individuals of Hispanic ethnicities are $18 \%$ of the general population, yet they represent $21 \%$ of the houseless population. Native Hawaiians and Pacific Islanders numbers in the houseless population is $1.3 \%$ which is $6.5 \%$ higher than their proportion of the total population $(0.2 \%)$ and individuals who identify with two or more racial groups are $5 \%$ of the houseless population yet their percent of the general population is $2.3 \%$ of the total population which is more than double disproportionately represented in houseless populations (National Alliance to End Homelessness, 2018, https://endhomelessness.org/resource/racial-disparities-homelessness-united-states).

\subsection{Oregon and the Statistics on Houselessness for 2017}

The data from the Point-in-Time counts for 2017, an annual count of the houseless population in the city of Portland utilizing volunteers who walk the streets in Portland and count houseless individuals. Estimated the number of homeless individuals and families with children experiencing houselessness was 13,953 in the state of Oregon. Of the total population of houseless individuals 3,519 had families with children, 9,829 were individuals without children, and 605 were unaccompanied youth under the age of 18 . The study noted that individuals with children were sheltered at a rate of $48 \%$ or 1,689 of the population, leaving $52 \%$ or 1,830 unsheltered. Individuals without children are sheltered at rates of $43 \%$ or 4,226 , leaving $57 \%$ or 5,603 unsheltered individuals. Unaccompanied youth are sheltered at $18 \%$ or 109 youth, leaving $82 \%$ or 496 unsheltered individuals. It also noted that $24 \%$ or 3,387 of the total population of 
homeless individuals are considered chronically houseless. When an individual has been living on the streets for more than three years, they are considered to be chronically houseless (The Portland Housing Bureau Report, 2017). The report noted that caution should be taken when identifying trends in the number of people experiencing homelessness as they are a transient population. Many factors affect the results of the Point-in-Time count including changes in methodology, volunteer availability, agency staff involvement, and weather conditions.

(http://www.oregon.gov/ohcs/ISD/RA/2017-Point-in-Time-Estimates-HomelessnessOregon.pdf).

\subsection{Definitions of Houselessness}

One of the many problems that plagues efforts to study houselessness lies in the definition of what circumstances render an individual to be considered houseless. For this research, I utilized the definition from the Department of Housing and Urban Development (HUD) and added an additional element. The HUD delineates four categories of being homeless: 1) Individuals and families who lack a fixed, regular, and adequate nighttime residence and includes a subset for an individual who is exiting an institution where he or she resided for 90 days or less and who resided in an emergency shelter or a place not meant for human habitation immediately before entering that institution; 2) Individuals and families who imminently lose their primary nighttime residence; 3) Unaccompanied youth and families with children and youth who are defined as homeless under other federal statutes who do not otherwise qualify as homeless under this definition; or 4) Individuals and families who are fleeing, or are attempting to flee, domestic violence, dating violence, sexual assault, stalking, and or other dangerous or life-threatening conditions that relate to violence against the 
individual or a family member (HUD, 2013). I submit a fifth criterion used by Choco et al for individuals who are "couch surfers." This phenomenon takes place when an individual is doubled-up sleeping with family or friends and their name is not listed on the rental agreement (Choca et al., 2004). Due to the transient nature of houseless individuals, there are no current records on the unique population of couch surfers, nor are there services specifically designed to aid these individuals in exiting houselessness. Subsequently, they remain a silent vulnerable population.

\subsection{Homeless - Houseless}

Out of respect, this definition is extended to houseless individuals who consider "home to be where the heart is," and a house to be the physical structure in which one lives. They choose to be identified as "unhoused or houseless persons." In keeping with the self-identities of this population, I utilize the terms unhoused or houselessness interchangeably with homelessness.

As the population of houseless individuals has grown, researchers have studied the causes of why individuals find themselves in a state of houselessness. Past research studies have demonstrated an impressive understanding of the causes and consequences. The origins defined by researchers of houselessness are: abuse, trauma, poverty, addiction, mental illness, inadequate housing, inadequate employment opportunities, and lack of affordable housing (Abbott, 2008; Caton, C.L., et al., 2005; Cheng, Tessa et al., 2013; Clarren, 2005; Karabanow, 2008; Rollins, Chiquita et al., 2012; Shelton, K.H., et al., 2009). The focus of identifying the causes of houselessness is vital in understanding the ways in which individuals exit (Karabanow, 2003). Not only is there a lack of research into the processes and ways in which individuals exit houselessness, there is limited research that captures the perspective of individuals lived 
experiences of what factors aided them in transitioning to conventional housing. This study is designed to capture and highlight the "upward spiral" of individuals who have been able to secure housing stability (Thompson, Pollio, Enrich, Bradbury \& North, 2004). This research design was developed with the intention of aiding understanding and closing the gap on the number of individuals who successfully exit life on the streets.

\subsection{Purpose and Research Design}

The purpose of this qualitative study is to unearth the emergent themes and processes through in-depth interviews of houseless individuals' experiences with pathways out of houselessness and the factors that allowed for such transitions. Qualitative in-depth interviews have a two-fold benefit; they enable the researcher the opportunity of observing and recording from the perspective of the participants, and for the participant, they provide a unique opportunity to reflect on and share their experiences about what services aided their exits. The sampling method of this study is initially via an informant who served as a gatekeeper. Snowball sampling techniques were utilized at the time of interviews to solicit additional participants. It highlights their scripts of self-identity, survival skills, coping mechanisms, and life experiences.

This study does not intend to be statistically representative of the total population of houseless individuals. Instead, it provides a cross-sectional view of previously houseless individuals' experiences with transitions, social service agencies, and various forms of social support networks in the city of Portland, Oregon, with the objective of offering some interesting theoretical insights into the process of gaining housing stability. It is the endeavor of this research to provide policymakers with information 
that may increase the functionality of programs to further aid individuals as they exit life on the streets.

This section serves as a roadmap to my thesis. Chapter Two is the Literature Review that describes known research on the topic. Followed by Chapter Three, Theoretical Framework and then the Data and Methods section as Chapter Four. Chapter Five presents the Findings which has been partitioned into sub-headings of emergent themes. Chapter Six contains the Discussion. Chapter Seven is the Conclusion which describes the Policy Implications, limitations of the work and opportunities for future research. 


\section{CHAPTER 2 \\ LITERATURE REVIEW}

I subdivided this section in order to highlight key emergent themes found in existing literature. I analyze the literature in relation to their role in ways that impact individuals as they exit houselessness: major causes of houselessness, the impacts of social networks, friends, family, and associations, social service agencies and supportive networks, and subjective well-being and happiness, this study seeks to understand the roles and contribution that each of these variables play on the experiences of individuals as they exit houselessness. I conclude this section with an overview of the literature and the connections to my research questions on the pathways individuals utilize as they transition into mainstream housing.

\subsection{Major Causes of Houselessness}

The number one leading cause of houselessness is insufficient income paired with a lack of affordable housing (National Low-Income Housing Coalition (NLIHC), 2014). In 2012, 43 million Americans rented the properties in which they lived, and of that number 10.3 million renters were classified as having extremely low incomes (ELI). That equals one in four renters who are spending more than $30 \%$ and upwards of $60 \%$ of their gross monthly income in rent, creating a deficit for all other living necessities such as food, medicine, transportation, and childcare (National Alliance to End Homelessness, Homelessness Looms as Potential Outcome of Recession (2009). These individuals are defined as pre-homeless and it is widely accepted that one loss in financial stability (e.g. loss of employment, uncovered medical expenses, and loss of income from one family member) would place them in a state of houselessness 
(NLIHC, 2014). In that same year (2014), only 5.8 million rental units were classified as affordable housing, leaving the 4.2 million Americans in a state of housing instability (National Low-Income Housing Coalition, 2014). Furthermore, only 31 out of 100 of those available units were available to individuals who classified as ELI.

The foreclosure crisis that began in 2008 has played a significant role in the increasing numbers of houseless individuals in the United States. In 2008, state and local houseless service agencies reported increases in the populations of up to $61 \%$. A secondary cause of the rise in houseless people was due to renters being evicted as a result of foreclosures of the landlord's primary residence (National Alliance to End Homelessness, Homelessness Looms as Potential Outcome of Recession (http://www.besidestillwaters.net/sitebuildercontent/sitebuilderfiles/file_projected_ho melessness_increases.pdf).

Women fleeing domestic violence from their primary residence is the number one leading cause for women who are experiencing houselessness in 2006 (Tischler et al., 2007). Finally, in a national annual conference of mayors from cities across the United States explored issues surrounding houselessness and the key causes of the increase in houseless families concluded the lack of affordable housing, unemployment, poverty, and low wages. In the same report, the leading causes of houselessness among single individuals was coupled with mental illness. Currently, houseless families receive comparatively more assistance from service agencies than single houseless individuals. Policymakers have acknowledged that this inequity must be considered when designing programs that assist individuals in achieving housing stability (U.S. States Conference of Mayors, Hunger and Homelessness Survey: A Status on Hunger and Homeless in America's Cities - A 25-City Survey, 2014). 


\subsection{Impact of Social Networks, Friends, Family, and Associations}

“Abuse, Support, and Depression among Homeless and Runaway Adolescents" (Bao, W.N., Whitbeck, L.B. \& Hoyt, D.R.) focused on the prevalence of depression in homeless and runaway youth. It defines various effects of social relationships on houseless individuals. The positive effects are stress reduction, sources of mentoring, information and support while the negative effects of social networks include victimization, engagement in aggressive or coercive interactions with others. The findings in this study bring clarity to social networks and how they might affect the outcome of houseless individuals. Within the houseless community, individuals exhibit strong social ties that can surpass familial ties where individuals are seen as a part of a communal family. Individuals learn the tricks of the trade of maneuvering through houselessness from their peers and such supports extend to referrals of shelters, social service agencies, food donation sites, and safety patrols (Bao et al., p 416 2000). It is these connections that allow individuals to learn of agencies that assist individuals in finding housing "when they are ready." These social networks are the foundation of survival for individuals who live life on the streets. The article below examines these networks and brings clarity to the function, formation, and attributes of the different types of networks that exist in the houseless community.

In the article, "Informal Non-Kin Networks Among Homeless Latino and African American Men: Form and Functions," Molina describes three different types of supportive networks that homeless people utilize: 
1. friends whom they have known for a long time and who are highly regarded in terms of personal intimacy, loyalty and trust;

2. associates with whom they have less well-established relationships, yet they maintain frequent contact with them, sometimes have an emotional regard for them, and have an active exchange of resources with them; and

3. casual or "satellite" acquaintances, who span the outer edges of skid-row relaying information to familiar yet detached others with whom they have minimal contact.

Friends consist of non-kin networks who serve as a pseudo family. These members give a variety of supports on a daily basis: companionship, sharing food, and living arrangements. Friends offer an array of social supports, but the most profound support comes in the form of elevating one's self-esteem. Associates were somewhat distant friends depending on the frequency of contact along with their personal and emotional ties to these individuals. In this group, you find some distance in these relationships as they do not interact on a daily basis; however, they maintain a connection. In the third category, casual or satellite acquaintances are houseless individuals who exchange informational resources and provide personal safety along with information on programs which offer overnight sleeping arrangements, food and donations (Molina, $\mathrm{p}$. $672,2000)$.

In "Homeless not Hopeless" Molina adds to the categories of networks by highlighting the relationships between houseless individuals and individuals who work for social service agencies/networks. According to Molina, these relationships cover public welfare agencies to private social service organizations that provide a variety of 
services to houseless individuals. Molina included these providers as they play an integral role in housing transitions by offering services that aid houseless individuals such as: counseling; job-readiness assistance; transportation; shelters; medical treatments and housing placement services (Molina-Jackson, 2008). The relationship that are formed while individuals are houseless can have positive and negative consequences in the report listed below,

In the article, "Brief Report: Youth Pathways Out of Houselessness" it reported that factors such as drug use, structural support, housing availability, exposure to criminal justice systems, employment availability, and breaking ties with street culture were significant indicators for successful exits (Kidd, S.A., Karabanow, J., Hughes, J., Frederick, T., 2013). Although this study was focused on youth who exited, adults who exited reported similar barriers which is confirmed in literature. The time an individual lived on the streets showed a direct correlation to the ease of adjustment to housed living. For individuals who remained on the streets for a significant length of time of 3 years or more, the adjustment of living in conventional housing were more difficult as these persons lacked have strong social ties with housed persons (Kidd et al. 2013). Again, we see that social ties are an important factor when individuals seek to return to conventional housing. They further noted in their findings that cutting ties with street culture was a reliable indicator of the success for individual transitions (Kidd et al. 2013). The following section explores how houseless individuals utilize social service agencies and learn about programs and services that help pave their way out of houselessness. 


\subsection{Social Service Agencies and Supportive Networks}

In "Getting Off the Streets," Karabanow highlights the importance of social service agencies and the role they play in aiding houseless individuals in transitioning to conventional housing. The study also noted that social service agencies help individuals gain a renewed sense of self. Within the study, participants viewed many service providers as surrogate families, and brokers between living on the streets and conventional housing. Karabanow noted the services that agencies provide that are most impactful are shelters, drop-in centers, outreach programs, and the support of basic needs while they were houseless and throughout the exiting process. Additionally, they provide employment assistance, training, mental health care services, dental, mentoring, counseling, and care for animals of houseless individuals. Agencies aid individuals through the exiting process as well by offering housing placement services, classes on cooking, budgeting, education, and personal safety training. According to Karabanow, houseless individuals rely on the variety of services to meet their immediate and basic needs (Karabanow, 2008).

Finally, in the study "Service Utilization among Homeless and Runaway Youth in Los Angeles, California: Rates and Reasons" (De Rosa et al., 1999) it was determined that in Hollywood, California, 78\% of homeless youth used drop-in centers and $40 \%$ used shelters. Although, De Rosa's study is somewhat dated and focused on houseless youth, I utilize this research as many of my participants were homeless during their youth and the habits they formed as houseless individuals developed during that period in their lives.

Scholarly research is limited on the topic of service agency usage of shelters, food, housing, and street outreach programs among the houseless. The articles that do exist on this topic tend to be directed to the cities in which houseless individuals reside. The 
advantage of reports of this type is that they focus on the unique experiences of individuals who utilize their services. This allows service providers the ability to track usage and create programs that address the specific needs of individuals in a particular geographical location. Accessibility of services for houseless individuals is determined by the quality of services offered in the city in which the individual resides. For example, if a particular city has no shelter for families with children these individuals will have to find alternative ways of finding housing such as "couch surfing", staying in their car or with friends, or sleeping on the streets. In the following research report De Rosa offers insight into the willingness of houseless individuals to utilize service agency supports.

De Rosa also noted that houseless individuals are more likely to use social service agencies when they are offered services that are confidential because they bolster feelings of safety. Safety concerns and perceived risk are also a contributing factor in the likelihood of an individual utilizing a shelter or drop-in center. De Rosa found that individuals were more likely to utilize service agencies that require little to no paperwork, had informal rules, and no requirement for identification in order to stay in accommodations. Additional factors that influence use of service agencies among the houseless includes race/ethnicity, peer group, gender, and sexual orientation. The findings report several linkages between peer group and ethnicity: Youth associating with punker-peer group tended to be Anglo-American and less likely to use medical or dental services than gang-affiliated Afro-American youth and Latino-Americans. When service providers tailored services to certain groups such as individuals who identify as gay, lesbian, bisexual, and transgender, they were more likely to use services when agencies were respectful of their lifestyles. Agencies that provide additional safety 
services to female houseless individuals were also highlighted in their findings (De Rosa et al., 1999; Ray, N. 2006).

The intersection of these four variables: confidential services, safety and perceived risk, informal rules, and no requirement of identification offer an intriguing insight into how houseless individuals utilize similar types of services as their peers as exit strategies. The following section explores literature regarding the utility of resilience and personal happiness as it impacts one's ability to exit houselessness successfully.

\subsection{Subjective Well-Being and Happiness}

Measuring happiness among unhoused or newly housed individuals is rather difficult; measuring the degree of one's satisfaction while they experience houselessness can prove to be quite challenging but may yield valuable data. In the article, "The Subjective Well-Being of The Homeless and Lessons for Happiness" (Biswas-Diener and Diener 2006), the author gives insight into how individuals adapt even in hopeless situations such as houselessness. In his study, Biswas-Diener interviewed three independent groups of houseless individuals: Group A were street dwellers living in Calcutta, India; Group B houseless people who resided in Fresno, California, and Group C houseless individuals living in "Dignity Village" in Portland, Oregon. It reported that individuals from India scored higher levels of subjective well-being as compared to individuals living in California and Oregon. The findings reported that all individuals reported higher levels of self-esteem indicating that their circumstance of being houseless is not a determining factor in self-esteem.

Biswas-Diener and Diener also noted that social networks play a vital role in the overall ratings of subjective well-being, indicating that good social relations are necessary for a sense of well-being (Biswas-Diener, Diener, 2006). Their findings reported that 
across all three groups houseless individuals were genuinely dissatisfied with the physical demands of life and all groups exhibited high levels of food satisfaction. All three samples reported surprisingly high satisfaction with factors related to self and mortality, intelligence, and physical appearance. The researchers report that even though homeless individuals experienced physical and emotional hardships, they tended to like themselves and reported above-average levels of self-confidence. In separate research, Kidd and Davidson found that social service agencies reported higher rates of success when they utilized strength-based approaches that focus on client's resilience and personal strength to empower them to take control over their lives (Kidd \& Davidson, 2007).

An additional interesting finding from the Biswas-Diener and Diener study was that people living on the streets in Calcutta, India reported high levels of self-appraisal (i.e. self-esteem, self-confidence); however, in the United States individuals reported low levels of self-appraisal. The authors concluded that in Calcutta, the predominant religion is Buddhism which teaches that one's success is not tied to their earthly possessions nor their worth, whereas individuals living in the United States are stigmatized and alienated due to their lack of success in obtaining worldly possessions which is a sign of their worth in U.S. society (Biswas-Diener, Diener, 2006; BiswasDiener and Seligman, 2002).

The findings suggest something different from what we typically understand regarding the effects of houselessness, deprivation, and the lack of basic needs. In social science, is the assumption that basic physical needs such as food, water, and shelter must be satisfied before a person can achieve psychological fulfillment (Maslow, 1954). It is believed that when a houseless person gains access to food and shelter that they will 
report higher levels of increased psychological health (e.g., subjective well-being, happiness). Contrary to Maslow's work, according to authors, happiness or subjective well-being is not connected to one's physical or tangible possessions, it is thought to be more a frame of mind than a state of circumstance (Biswas-Diener and Diener 2006). For Biswas-Diener and Diener, the comparison is essentially that of individualism vs collectivism in a societal structure and how the overall frame of mind is perpetuated on individuals living in a state of houselessness. In a collectivist culture the individuals are not demonized for their homeless state but instead are viewed as victims of social ills. In collectivist cultures the fault of one's state is not placed upon the individual - it is placed on the society as a whole. However, in individualist cultures, such as the United States the individual is treated as an outcast and by not working and contributing to society he/she is considered to be the problem in the society and deserving of his/her circumstance.

This study focused on the effects of living in each society and being houseless and how it affected their subjective well-being. Research studies have explored the problems surrounding houselessness and the ills that plague individuals through their lack of conventional habitation (Kidd, Karabanow, Hughes, Frederick, 2013). Research on subjective well-being suggests that individuals adjust to life's circumstances including adverse life situations and that the cultural restraints will affect the impact of the adjustment "Positivity and the construction of life satisfaction judgments: Global happiness is not the sum of its parts" (Biswas-Diener, Diener, 2006; Diener, NapaScollon, Oishi, Dzokoto, \& Suh, 2000). The study further suggests that when individuals adjust to adverse outcomes, their levels of subjective well-being be will be 
lessened (Biswas-Diener, Diener, 2006; Diener et.al., 2000; Silver, 1982; Loewenstein and Frederick, 1999).

The literature surrounding the effects of houselessness on an individual has found that they suffer from mental and physical anxieties brought on by the trauma of being homeless. (Mayock et al. 2011) In this study, we can anticipate that we will find individuals who are houseless suffering from a mental and physical standpoint, thereby exhibiting low levels of subjective well-being across all spheres. In addition, to this, the collective findings from these studies suggest that individuals with strong social and familial ties and individuals who utilize social service agencies tend to have higher levels of subjective well-being/happiness and are more likely to employ agency assistance when transitioning into conventional housing.

\subsection{Summary}

The salience of these five emergent themes found in literature are the foundation for this study and are as follows: major causes of houselessness; impacts of social networks friends, family, and associations; and social service providers. The major causes of houselessness according to literature are housing costs in relation to wage inequity. The literature suggests that individuals who have active social networks and positive senses of subjective well-being and happiness are more likely to utilize social service agencies as a pathway out of houselessness. Social networks, friends, family and associations (if positive) play a pivotal role in individuals who successfully exit by sharing and exchanging information, resources, and providing personal safety. Individuals with personal relationships were found to have higher rates of obtaining permanent housing (Kidd et al., 2013). Social service agencies that bolster positive interactions with houseless individuals tend to increase the likelihood of successful exits. Agencies that 
offer confidential services and informal rules increase the likelihood of Individuals in achieving housing stability. It was also noted that when houseless individuals limit interactions with currently houseless individuals it decreases the rates of recidivism. These factors are merely indicators and not an exhaustive list of characteristics or preferences that an individual must possess in exiting houselessness. There is no one single program that is going to fix the current problem of houselessness. It is going to be the concerted effort among government and state officials, social service agencies and researchers who study the effects and the experiences of individuals who find themselves without housing. As we have learned in research regarding houselessness, there is no "one size fits all" program, but instead several programs coming together to address the diversity of individuals who find themselves living without housing. In the following chapter, I discuss the theoretical framework of this study which are the grounding blocks of this research. The two theoretical frameworks that I utilize are "Habitus" (Bourdieu 1977: p72; Wacquant, 1995) and "The Networking Theory of Strength of Weak Ties" (Granovetter, 1973). 


\section{CHAPTER 3 \\ THEORETICAL FRAMEWORK}

The Theory of Habitus (Bourdieu 1977: 72; Wacquant, 2011) and the Framework of the Strength of Weak Ties: A Network Theory Revisited (Granovetter, 1983) are the conceptual frameworks for this study. When an individual becomes houseless, they are placed into a group or class of individuals from whom they learn the norms, values, and tricks-of-the-trade of living life on the streets. This is the expression of one's habitus. Habitus is the process of how we acquire norms, values behaviors, perceptions, which shape our experiences. Habitus is being defined as the totality of one's resources which include social capital, (i.e., education, social class, and networks) economic capital (i.e., (money and wealth), it is the totality of acquired experiences, and is expanded by dayto-day interactions.

The utility of Strength of Weak Ties is exemplified through the usage of networking that exists within the houseless community. Individuals share information or resources such as shelters, medical clinics, food, and programs that aid individuals and exiting houselessness. "The Strength of Weak Ties" explains one's acquaintances as weak ties and friends as strong ties. We share the same information as our friends, drawing from the same ideas and conclusions. However, our acquaintances offer different knowledge or resources making those relationships more valuable when seeking knowledge and or resources beyond our immediate network.

\subsection{The Theory of Habitus}

Habitus according to Bourdieu is the understood traits which are common to a particular social group or class that shape all the practices of one's life. Habitus is not oppressive 
or coercing - it is the general habits of a specific group or class and is the lens through which members of a group come to know and execute those roles within a particular social group (Bourdieu 1977: 72). For Bourdieu, one's habitus references their habits, perceptions, actions, and practices and how they come to view themselves and others. The norms, values, and behaviors that are considered acceptable or unacceptable are all conveyed through the socialization process conveyed through one's habitus (Bourdieu, p. 248, 1986). Habitus an acquired behavioral pattern regularly followed until it is virtually involuntary: i.e. the habit of looking both ways before crossing the street. Habitus is the way in which members of a group come to know, understand, and execute roles of a given group in a particular social group. (Bourdieu 1986: 248).

In the article, "Habitus as Topic and Tool: Reflections on Becoming a Prizefighter," Wacquant (a student of Bourdieu's) reflects on his search for a setting in which to empirically test the utility of habitus. He stumbled upon the Chicago boxing gym, centered southside Chicago an Afro-American neighborhood, where he tested his hypothesis of the utility of habitus as a theoretical framework. He elaborated empirically on Bourdieu's concept of habitus by becoming a boxer himself as a way to understand the ways in which an individual is inoculated into the subculture of boxers:

"For three years, I melted into the local landscape and got caught up in the game. I learned how to box and participated in all phases of the preparation of the pugilist, all the way to fighting in the big amateur tournament of the Golden Gloves. I followed my gym buddies in their personal and professional peregrinations. I dealt on a routine basis with trainers, managers, promoters, etc., who make the planet of boxing turn and share in the spoils of this "showbusiness with blood" (Wacquant 1998c). 
For Wacquant, habitus is not the answer to the question. It is a manner in which one asks questions about the social world. Wacquant's accounts of pugilism demonstrate the utility of habitus and this example can easily be transferred to houseless individuals. One enters the subculture of houselessness, learns the norms and values of that group, assumes a role or position in that group, and then the enactment begins.

\subsection{The Utility of Habitus to the Houseless}

According to Wacquant, with each transfer into a new group our habitus is increased and this process will continue throughout one's life. He viewed these day-to-day interactions of group dynamics like an actor playing his or her role from a script. Individuals who become homeless develop a new set of habits, skills, and characteristics to act in this new role; they become street smart and learn the necessary behaviors. If that same individual were living in an upper-class neighborhood before they became homeless, they would have a different set of skills that would not translate in this new role and in order to act the part they would have to make adaptations.

When an individual becomes houseless, they have to learn a new set of skills. This is a time according to Wacquant when the individual's habitus is increased. They learn from other houseless individuals the day-to-day actions which are necessary to survive life on the streets. It is during this time they learn about various resources such as free meals, food donation centers, shelters, free medical clinics, and programs that aid individuals in transitioning to conventional housing. These individuals may access habitus from the past-lived experiences of individuals who have survived on the streets or transitioned into conventional housing. This study argues that such access may aid houseless individuals with the working knowledge that houseless exits are possible. 


\subsection{The Networking Theory of Strength of Weak Ties}

The core theoretical framework of this research project relies on the theoretical framework developed by Granovetter in his work, "The Strength of Weak Ties" (Granovetter, 1983). According to Granovetter, "strong ties" promote cohesion within a group such as the houseless while it simultaneously limits access to external resources unknown to the group as it lacks diversity and consequent exposure to information about additional resources. Conversely, "weak ties" lead to less cohesion within social networks but increase the likelihood of broader network/connections and indirect exposure to other available resources. Granovetter's work ultimately describes how weak ties may provide a more diverse body of knowledge and resources to draw from than strong ties, ultimately offering more assistance in exiting houselessness (Granovetter, 1973).

\subsection{The Utility of The Strength of Weak Ties}

Through the day-to-day social interactions of houseless individuals, it is noted that both strong and weak ties develop between members of this disenfranchised group. However, it is the weak ties that are the underpinning of this study. Relationships that are distant, casual, and informal form weak ties; there is less similarities among members, thus new and unrelated information is being offered and exchanged such as resources on exiting. I argue that individuals who are houseless will find services through their weak network ties in keeping with this underpinning theoretical perspective.

This conceptual framework is useful to consider as houseless individuals are known to have active social networks as noted in the "Point in Time Counts" report produced by the Portland Housing Bureau (Portland Housing Bureau, 2017). Ironically, although 
these bonds are influential and vital in the day-to-day survival of houseless individuals, they can also hinder many from exiting houselessness. In other words, the stronger the ties, the more limited the potential exposure to information about additional resources and support (unknown and unused by group members) and a lesser consequent opportunity to exit from houselessness. With strong ties, group members become indistinguishable and are therefore unable to add new ideas and pathways due to their congruent and overlapping resources. Strong ties are homogenic, meaning the group members are in close associations to one another and provide little variance in the types of usable information which can be transferred between members. Members of such groups can offer little assistance to one another beyond a limited sphere as they have similar networks and resources. The dynamics of these groups may lead to a perpetual or chronic state of houselessness as the members lack diversity in their experiences. On the other hand, however, when an individual is in a network of friends from distant social groups, they have a different set of resources presented to them. In this sense, accumulating "weak ties" in different social networks may directly increase the opportunities to exit houselessness. Weak ties offer diversity and exchanges of new information that prove necessary in exiting. The divergent information that is exchanged in weak ties is the building block for the theoretical utility of the strength of weak ties.

This study focuses on understanding pathways out of houselessness from the perspective of the lived experiences of individuals who have done so successfully. The investigation aims to access the viewpoints of those individuals who have tracked into mainstream housing and to learn what skills or social networks these individuals utilized to get off the streets. The research questions elaborated upon below are 
designed to augment understanding of these experiences and the social issue of houselessness. The findings of this project may prove beneficial to service providers, other persons who work with this population, and allies who may want to provide support to individuals as they exit houselessness. The questions of this research study utilize both theories, habitus (Bourdieu 1977: 72) and Strength of Weak Ties (Granovetter, 1973) to focus on the specific research questions:

1. What social factors and experiences as reported by research participants influence the ability of houseless individuals to move into conventional housing?

2. What are the resources and support services used by those who successfully transition into traditional housing?

Individual trajectories to varying degrees affect one's ability to utilize habitus, as well as the strength of weak ties as an exit strategy out of houselessness. Although the overall structure is varied, some individuals are able to access their forms of habitus and networks based on their experiences of being houseless and rely on these as an exit strategy.

In the next chapter I focus on the methodology of this study. I describe the procedures of this study, explain the processes and procedures in participant participation, procedures of data collection, and analysis. 


\section{CHAPTER 4 \\ METHODOLOGY}

Given the exploratory nature of this research, a general inductive approach was utilized in the methodological design. This approach utilizes a set procedurals process that analyzes data in a systematic manner (Thomas p. 238, 2006). A general inductive approach is well suited for gathering data from in-depth interviews and for the interpretation of emergent themes held in data. General Inductive Methodology is a time-honored approach in qualitative research, utilized for yielding in-depth insights as well as the possible development of theory (Thomas p. 238, 2006).

This qualitative study employs in-depth interviews as the primary method of data collection with formerly houseless individuals. In-depth interviews allow for probing beneath the surface, soliciting details and providing a holistic understanding of the interviewee's point of view (Patton 1987: 109). Interviews are a conversation with a purpose allowing the exchange of views and experiences that are often void in unstructured discussions (Thomas p. 238, 2006).

Interviews enable the researcher an opportunity to probe and inquire into the lived experiences of participants that may otherwise go unrecorded in the pursuit of studying social phenomenon such as how houseless individuals transition into conventional housing (Kavle, Brinkman 2009). Qualitative interviews as undertaken for this research begin with an interview guide consisting of open-ended questions structured with a specific objective allowing participants an opportunity to share their accounts while maintaining a degree of control over their exposure (Dick 2006).

Sharing my experiences of houselessness with potential participants is likely to aid in the interview process by removing the barriers that typically exist between researchers 
and participant (Appendix C). It may also aid in the quality of data by yielding richer more comprehensive information that would allow for better raw material for analysis. I created a study guide based on the research question and the overall design of the study (Appendix A). Interview questions probed participants about their lived experiences in street life in order to understand their pathways in their quest to obtain housing stability. Biographical information was included in the interview guide shows the results of this information (Table 1). The questionnaire also included questions that sought participant's recommendation for programs that would have aided their transitions.

\subsection{Participant Selection and Recruitment}

The population of this study was initially proposed for 12 to 15 participants due to the available time of the researcher and the expectations that the narratives collected would reveal valuable insights and hopefully some saturation in pattern of the experience of participants. Limiting the population of the study allowed the researcher sufficient time to understand the nuances that arise in analysis which may have been overlooked in a larger population.

The criterion for selection of this study:

1. An individual who was previously houseless

2. An individual over the age of 18 ,

3. An individual who is English speaking

4. An individual who is currently living in conventional housing.

In an effort to recruit participants, I posted flyers in several local agencies that assist individuals in obtaining housing. I posted flyers in facilities where previously houseless 
individuals reside. Due to the vulnerable nature and general inaccessibility of this population, this study employs use of an informant. Jade (informant) was once houseless himself for more than twelve years before he had transitioned into conventional housing. He remains in contact with the houseless community and personally knew several people who met my selection criteria. Jade worked at a local coffee shop I frequented during my time in college. We began to talk and I discussed my study proposal. Jade was very fascinated and offered to assist me with participants once I had all protocols in place.

Participants selected for study were recruited via this informant, which is strategic as houseless and formally houseless individuals remain in close contact in various ways such as walking the streets, doing well check-ups, or allowing a chronically houseless person shelter in the cold winter months (McCue, 2009).

Jade referred me three individuals by supplying me with their phone numbers, I verified with him that the potential participants had given their consent for me to contact them before contacted them by phone. I called each potential participant and explained who I was and gave a brief overview of the study and asked for their voluntary participation. We made an appointment to meet at the university in one of the empty classrooms in the sociology department. Before each interview began, participants were given an informed consent form. I also shared and a list of free counseling services should any questions cause discomfort (Appendix E). I read the outline of the study, to them and reassured them that they could refuse to answer any question or decide to end the interview and withdraw from the study at any time without any negative consequences. After the informed consent was signed, each interview began with an opening statement 
detailing the focus of the study, types of questions, and an outline of the interview (Appendix C).

I shared my reasons for choosing this topic with the participants and explained how agreeing to be interviewed gives voice to a marginalized population. After the interviews I asked research participants if they would refer me to anyone who may want to participate in my study. I used non-probability, snowball-sampling methods to locate the other nine research participants once the interview process was complete (Moore 2007, p. 444).

The study concluded with the narratives of 12 previously houseless adults who met the selection criteria. All participants who met the selection criteria and displayed interest in participation were interviewed. All potential research participants I contacted agreed to participate in the study. Each participant was given a packet of information containing a copy of the consent form, a recruitment flyer (Appendix D), and compensation for their time ( $\$ 20.00$ and an assortment of snack products). Table 1 reports the demographical information of each participant, as well as their time spent while houseless. Participants were allowed to self-identify for race/ethnicity, and gender.

The interview guide consisted of 18 open ended questions and 12 questions of basic demographic information. Interviews were scheduled for one hour although I allowed participants to speak freely in their own words and share their experiences of exiting houselessness. 


\subsection{Data Collection}

Upon the reviewing participant consent, the interviews were digitally recorded using a cellular device. When answering research questions, participants were encouraged to speak freely. In total, the range of interviews was between 55 and 70 minutes. Interviews were conducted individually to ensure that the anonymity of all participants was strictly maintained. Questions were open-ended with probes for participants when eliciting elaboration and clarification (Appendix A). Any identifying information was kept in a locked cabinet with only myself and my advisor having access to the documents and audio recording. All personal identifying information of the participants was removed and pseudo names were given; only myself and my committee chair had access to the original participants records. Participants were asked about their individual experiences as houseless individuals and what experiences they had with organizations and support networks as well as their overall experiences of their pathways out of houselessness. Participants were also invited to share any additional information they thought would be helpful. At the close of each interview, participants were also asked for recommendations for improvements to services or agencies that they believe might have aided them in their transition.

\subsection{Data Analysis}

In an effort to remember the nuances present in the data, I began transcribing as soon as the interviews took place. This proved helpful, as transcriptions fail to recreate "the original language and flow of the discussion" of the conversation. They do offer the closest account we have while preserving anonymity and confidentiality for the participant (Poland 2002, 632). All identifying markers were removed from the transcripts to maintain confidentiality and anonymity of participants. Transcriptions 
were analyzed using the coding software - Dedoose. The initial coding was performed in a manner to identify emergent themes which were then coded into families.

The coding from Dedoose identified seventeen parent codes: Institutionalization, Criminal Justice Systems, Domestic Abuse Centers, Drug and Alcohol Programs, Cultural Capital, Economic Capital, Social Capital, Strong and Weak Ties, Family Friends, Habitus, Social Networks, Agency, Feeling of Home, New Self-Identity, and Possible Programs these codes emerged from the initial process of analysis. I further examined the parent codes and merged any overlapping themes of similar nature. The child codes where all unique and I kept the categories intact. The result of analysis was seven emergent themes were: (1) Made Up Mind; (2) Social Networks; (3) Social Service Agency; (4) Resilience; (5) Feelings of Achieving Housing Stability; (6) Change in Social Networks; and (7) New Identity. 


\section{CHAPTER 5}

\section{FINDINGS}

In this chapter, I report the findings in relation to the research questions.

1. What social factors and experiences as reported by research participants influence the ability of houseless individuals to move into conventional housing?

2. What are the resources and support services used by those who successfully transition into traditional housing?

\subsection{Demographic Participant Information Table}

At the time of interview, the biographical information of all participants was obtained, to note if any intersections of identity had an impact on an individual's ability to transition out of houselessness. We know from previous research that women and minorities experience greater rates of houselessness (De Rosa et al., 1999; Ray, 2006). Collecting this information may bring insight into the findings of this study (see Table $1)$. 
Table 1. Participant Demographic Information

\begin{tabular}{|c|c|c|c|c|c|c|}
\hline Participant & Age & Race & Gender & $\begin{array}{c}\text { Age } \\
\text { Became } \\
\text { Houseless } \\
\end{array}$ & $\begin{array}{c}\text { Age } \\
\text { Overcame } \\
\text { Houselessness }\end{array}$ & $\begin{array}{c}\text { No. of } \\
\text { Times } \\
\text { Houseless } \\
\end{array}$ \\
\hline James & 36 & White & Female & 21 & 34 & 2 \\
\hline Maximus & 27 & $\begin{array}{l}\text { Hawaiian, } \\
\text { Portugese, } \\
\text { Caucasian }\end{array}$ & Male & 17 & 25 & 3 or more \\
\hline Isis & 44 & White & Female & 30 & 41 & 2 \\
\hline Dick & 55 & Black & Male & 33 & 41 & 3 or more \\
\hline Justin & 47 & White & Male & 35 & 43 & 3 or more \\
\hline Lexus & 61 & $\begin{array}{c}\text { Native } \\
\text { American }\end{array}$ & Female & 27 & 57 & 3 or more \\
\hline Chance & 36 & $\begin{array}{l}\text { African } \\
\text { American }\end{array}$ & Male & 19 & 36 & 2 \\
\hline Thelma & 45 & $\begin{array}{l}\text { Mexican and } \\
\text { Puerto Rican }\end{array}$ & Female & 44 & 45 & 2 \\
\hline Katrina & 58 & Black & Female & 53 & 54 & 1 \\
\hline Kendrick & 24 & White & Male & 20 & 22 & 1 \\
\hline Willington & 26 & $\begin{array}{c}\text { Native } \\
\text { American, } \\
\text { Hawaiian }\end{array}$ & Male & 23 & 26 & 1 \\
\hline Vera & 55 & Black & Male & 30 & 32 & 2 \\
\hline
\end{tabular}

\subsection{Demographic Information Related to Findings}

The above table represents the biographical information of participants of this study. Of the twelve participants, there were five females and seven males. Four of the research participants were Afro American/Black; four participants were Anglo American/White, three identified as multi-racial, and one was Native American. 
Participant biographical information related to the findings of this research are explained below. Nine participants of this study (five females and four male) utilized the services of agencies which assisted them in returning to conventional housing. The three remaining participants utilized family and friends as a way of exit. The three participants (two women and one male) in the study who received no assistance from agencies in their process of returning to conventional housing were all couch surfers. It appears that participants of the research study who couch surf are less likely to utilize the services of agencies when transitioning into conventional housing. It is interesting to note that the three individuals who exited without agency assistance leveraged various forms of social capital which is the utility of habitus.

Three research participants of the total population were placed into housing upon their release from the criminal justice system. Two of the three participants placed in housing upon their release from the criminal system had prior recidivism history into houselessness. This experience would be greater understood when considering the "The Networking Theory of Strength of Weak Ties" (Granovetter, 1973). Individuals lacking the communal relationships that are created in the houseless community, are isolated and prohibited from learning of services that may aid them in exiting. They no longer returned to life on the streets once they decided that they were no longer going to live life on the streets. The Nine out of twelve participants dealt with recidivism into houselessness, the answers to this question were shared among participants Lexus share her response:

Lexus:

"there is no program that can keep you off the streets! You have to make up your mind that you want a different life and then you go after it'. 
The experience of exiting houselessness is different for each individual. However, thematic narrative analysis enabled the identification of developments common to participants. These common experiences of exiting houselessness allowed for the development of emergent themes noted in this section. Emergent themes such as My Mind's Made Up and Change in Social Networks listed below act as references of all emergent thematic narratives arranged in progressive order.

From a review of emergent themes, it became evident these shared experiences emerge in a sequential order. An individual has to have their mind made up as a first step in order for them to utilize the information that they obtain through social networks regarding exiting. individuals utilize various forms of habitus as they seek assistance of social service agencies, who in turn place them into programs that lead to transitioning into conventional housing. The fifth step is one in which the most passionate expressions came from participants as they share the experience of getting keys to their

new home. The sixth emergent theme comes at a time after achieving the goal of housing stability during which they experience a change in their social networks. Lastly, the seventh emergent theme happens once participants obtained housing they experience changes in their self-image or identity.

\subsection{Thematic Findings}

Tables 3 through 9 record the responses of participants to questions from the interview guide (Column A of Table 2), that produced emergent themes (Column B of Table 2), followed by definitions of the emergent themes (Column C Table 2). 
Table 2. Emergent Themes

$\begin{array}{ccc}\text { Column A } & \text { Column B } & \text { Column C } \\ \text { Interview Question } & \text { Emergent Theme } & \text { Definition }\end{array}$

11. As you reflect on your experience of houselessness what factors made you decide to seek conventional housing?

10. How did you learn about services that help people survive and exit life on the streets?

12. As you think about your experiences, what kind of services were most important to your transition off the streets?

13. As you reflect on how you made the transition, what factors about yourself or skills you have help you move from a life off the streets?

19. How do you feel you know that you have a place to call home?

16. Do you still have contact with people who are houseless? (Social Networks) If so what kind of contact? (Friends) (Financial Support) (Mentors) (Why or why not)

17.Tell me about the people you hang out with now that you are housed?
My Mind's Made Up The turning point when

(I am ready to exit individuals decide that they houselessness) were going to achieve housing stability.

Social Networks

(family, friends, nonkin, houseless individuals)

Social Service Agency

(e.g. programs as an exit strategy) (dependent exit)

Resilience
(as an exit strategy)
(Independent exit)

The ability of utilizing social capital as an exit strategy and achieving housing stability without the use of social supportive programs.

Feelings of Achieving Participants share how they Housing Stability feel now that they have achieved housing stability.

Change in Social Networks (after achieving housing stability)

Participants share how the impact of gaining housing stability, created a change in their social networks.
Participants share how the impact of achieving housing stability affected their social relationships. 
These emergent themes uncovered the phases in which individuals experience transitioning out of houselessness.

\subsection{Emergent Themes Tables 3-9}

Tables 3 through 9 capture the emergent themes with the corresponding question that invoked responses, along with a sample of responses that demonstrate that theme.

The experience of decision making can be a difficult one, especially if that decision may impact the rest of your life. Trying to choose between remaining in a state of houselessness or return to conventional housing is the first of a series of choices that participants faced.

Maximus, a research participant, shared his experiences with exiting houselessness. Upon his release from jail he was placed in a housing unit through a program within the city of Portland. Unfortunately, the housing unit was located in the same geographical area in which he had been living on the streets. This had a direct impact on his ability to maintain sobriety and he went back to using drugs and was removed from the program back to the streets. After some time on the streets Maximus became tired of living on his life the streets. He desired to stop using drugs and return to conventional housing. In his words: 
Maximus:

"I was ready! I wanted to stop partying and doing drugs I wanted to sober up and live a clean life. I went back to the housing unit and told the counselor I wanted help and he said no cause I had messed up the first time. I didn't realize I only got one chance and I wasn't on paper (probation)." "After a few days I was so fed up that I went back to the programs ran past the security guard into the counselor's office and screamed I shouldn't have to steal your car to get help but I will I know I messed up. I wasn't ready but I am now!" "And nothing can keep me from getting help not even you!"

Maximus reached that pivotal time when he was ready to leave the street life. He had friends who had gotten help, returning to housing stability. Unfortunately, not all houseless individuals share the same experience. According to Reitzes, the longer an individual remains houseless, the more likely they are to lose hope and become comfortable living life on the streets (Reitzes, et.al, 2011). Maximus was ready to return to conventional housing; his mind was made up.

\subsubsection{My Mind's Made Up}

Those who did make the decision identified a turning point. The decision may have been brought on by a traumatic event such as incarceration, death, or becoming disenchanted with street life. No matter what it was, there was a turning point that each participant reached. Participants spoke of determination and reported that once they made up their minds that they were going to find housing nothing could get in their way. Isis expressed her mind set and describes her reasons for leaving street life,

Isis:

"I was done with (it); I wanted something different, I wanted something more in my life and what I was doing for that last chunk of time being homeless wasn't getting anything more in my life so I just wanted something different". 
Justin made his decision as he looked to his future. His decision to exit was different from Isis but the results were the same.

Justin:

"I started seeing my future when I was on the streets in NE Portland. I got to know a ton of homeless pushing shopping carts full of cans smelling like pee. I started seeing that as my future and I said I can't do that."

James noted that they had no fear of losing their housing, because they had been houseless before and now had no fear of living life on the streets.

James:

"I have hit rock bottom and I survived it if living on the streets was the worst. I got this."

Lexus described it as a survival instinct and the desire for something different.

Lexus:

"That survival instinct. Yeah, it's got to be there man. Whether it's that fight or flight thing. For me, getting into stable housing was more of a flight-type response because I wanted to run away from whatever I had going on. Get me out, get me out, go. Yeah, it is that basic survival instinct and just wanting something different, a desire."

Statements such as these were common among research participants as they recalled clearly a point at which they made the decision to move off the streets. 
Table 3. My Mind's is Made Up

Question 11. As you reflect on your experience of houselessness what factors made you decide to seek conventional housing?

My Mind's is Made Up (I am ready to exit houselessness)

Participant

Vera

Vera

Katrina

Dick

Justin

Chance

Willington

James

Maximus

Thelma
"When I find something that is worth driving myself for, I usual achieve."

"I kind of made a deal with myself in my own little head, that if I went to prison that was it than I was done"

"I got tired of being put out! I decided to straighten out my life by quitting drugs.”

"I was at Tent City; I stayed there for two weeks. I was clean the whole time I was there. In the middle of all that mess and all that homelessness all that drama, I had my mind set on something different and I got that."

"One day I got fed up. This was not God's will for my life so I checked myself into Hooper because I was out there using drugs since I moved to Portland. It was crazy and I never thought that using drugs would land me homeless."

"The willingness to obtain a cleaner life. Become a better me and society. I am clean and sober, happy and content with my life."

"I wanted my family back; I wanted to be independent and stable. I wanted more, more of every positive thing that you can think of for life, I wanted more of that because I was not getting it, at all. I was just done."

"Honestly, I was tired of it. For the longest time I was like, I don't want to say proud of the life I was living but I was okay with it. It was comfortable for me for a long time. Right around the time, like in 2013 I started being embarrassed by it. And my thing is like if I am ashamed of something that I am doing, then I probably shouldn't be doing it."

"I needed to be safe. Safe from men, drugs and destruction and the willingness to obtain a cleaner life." 


\subsubsection{Social Networks}

The experience of living life on the streets from an onlooker's point-of-view may suppose that individuals are lonely, afraid, and in a constant state of worry due to the lack of habitation. Although living life on the streets can be dangerous and void of interpersonal relationships, there is another side that one may fail to see: the strong bonds, strong social ties and strong sense of community that exists in this community regardless of status or situation.

Participants had positive things to say about the amount of help that they received from other houseless individuals and many referred to it as a community. Participants in this research project had very positive things to say regarding their interactions with other houseless individuals.

According to Isis once you are in the community of houseless individuals you will never forget the bonds that you formed nor the struggles you faced because you are not alone. You are now in the family. As Vera explained, Vera:

"I am in the community and we help each other we are a family, and we will forever be, you never forget the struggle."

The networking capabilities in the community are far-reaching and individuals learn how to survive life on the streets from other individuals who are doing so. Some individuals learn how to panhandle, sell newspapers, get jobs, and learn about resources for permanent housing. In Kendrick's words, 
Kendrick:

"You learn to survive from other people who are in the same position. Pan handling, I sold papers to support my drug habit... did a whole lot of other things I learned from others."

Eight out of twelve participants spoke of supportive relationships and expressed a great deal of gratitude toward other houseless individuals. James, Thelma and Isis spoke of supporting other houseless individuals if they decided to go into treatment, sought referrals for employment, and wanted to gain housing. Participants spoke of their commitment to the community and to individuals who were trying to help themselves, and also were determined to honor the choices of others by not judging them because they chose to remain houseless. Dick explained his point of view,

Dick:

"Even if I don't agree with what you're doing I still feel obliged to help you. Cause you were there for me when I needed it because you help me find a place to call my own and I ain't never going to forget it."

The social networks that exist within the community of houseless individuals are supportive, life-changing, and unforgettable according to study participants. They are key way participants learned about support services and programs through that aided them in their exits. 
Table 4. Social Networks

Question 10. How did you learn about services that help people survive and exit life on the streets?

Social Networks (family support, friends, non-kin, individuals as an exit strategy)

\begin{tabular}{ll} 
Participant & \multicolumn{1}{c}{ Response } \\
\hline James & "I will come across times when special people in my life will go to \\
& treatment and I will drop everything I have going on to go buy them \\
& some t-shirts, boxers, and socks and I will go way out of my way to \\
& drop it off even if it is an area I don't like just to take them stuff to be \\
& supportive."
\end{tabular}

Isis I will always, if somebody wants to do something different and I have known you from the past, I will always do whatever I can to support that. I have gotten several people jobs through this company; you know what I mean, like I will be there.

Katrina "There are people who have actually gotten off the streets from information given to them from other homeless people."

Kendrick "I stuck with a lot of the people that were street smart and older than me. I saw how they handled it and mimicked it."

Maximus "I used a lot of inner personal skills, I built relationships with people when I was homeless, there was an older person out here in Portland that stood out different. He kind of took me under his wing and showed me the ropes yes, he was homeless. I would spend the night in the homeless shelters he showed. He helped me with a ton of resources to help me, he showed me this house that I could work there during the day to stay there and I got free meals. He told me to go down to TPI and they helped me a lot.”

Willington "My best friend and this older gentleman helped me find resources when I was homeless."

Sage "I got in trouble with the law, it made things difficult when trying to find a place to live a criminal background. Having my parents moved into town helped me transition off the streets. Having a place to shower and stay longer than the night made all the difference in my world."

Lexus "I found real nice people that had a little family friendly motel from India and they were so helpful. They would let us work out a plan so that we could stay there monthly they worked out a contract. People are kind to you if you are kind to them. If you are bitter or angry nothing opens up to you. Knowing how to get commodes in the community 


\subsubsection{Social Service Support}

Social service agencies play an essential role in helping houseless individuals return to housing stability. There are many different programs that are in place to aid houseless individuals, however without the aid of the houseless community and their networking many houseless individuals would have no way of knowing the various programs that assist them in exiting houselessness. Participants reported positive experiences when dealing with social service agencies. Participants praised the efforts of Central City Concern (CCC), Transitional Projects Incorporated (TPI), Veterans Administration Supportive Housing (VASH), Home Forward, and (NARA) Native American Rehabilitation Association. Table 4 captures participants reports of their experiences with support services. Justin shares about his experiences, Justin:

"TPI had a 3-6-month program to help me with shelter. I had to do chores, I applied at PCC and took a couple classes. I ended up getting money from going to school. I didn't have skills in employment so it was hard to escape houselessness. I just got my grant money and my girlfriend recommended that we moved in together and that is how I escaped houselessness."

The ability of having help when it was needed was very important to research participants. Housing was made available for four participants upon their release from a criminal institution. Life for them in an institution was a major adjustment and the move from prison back to life on the streets would have caused them great anxiety, they were relieved to be placed in housing. As James explained, 
James:

"Well I went to prison and I spent 3.5 years there. When I got out they put me into transitional housing. I still live in the same building that I been in since I got out of prison, I just live in the permanent housing part of it. I just never left the building because of security and safety."

And for Lexus the impact was similar,

Lexus:

"Prison saved me because I would probably be in the same spot as I was before I went in. They TPI gave me a place to live when I got out and I have been there ever since."

Drug and alcohol abuse is prevalent among houseless individuals, and programs that address substance abuse while offering housing services are especially helpful to participants. There are several clean and sober housing facilities throughout the greater Portland area that offer services that aid individuals in living a drug free life. Thelma shared her experiences in the following way;

Thelma:

"The Central City Concern helped me out so much, but even TPI, like those are the two big ones that I dealt with. The shelter where I stayed at, it is a shelter but it is a clean and sober like day center/shelter for men and it is run through TPI. If it had not been there for me, I don't know what I would have done. The Central City Concern, I went through their treatment center. I stayed at the $8 \times 8$, which is down by 8 th and Burnside. They have so many programs and options that you can get into, it's amazing”.

One participant spoke of the help he received from a social service agency which highlights the overall feeling that research participants experienced as they transitioned into conventional housing. Maximus shared his thoughts, 
Maximus:

"I think like, I would hate to say that Central City Concern is like everything in my world but it really is. It really is. I have seen Central City Concern and I don't really know of any other programs like it, you know what I mean?"

A key element that participants appreciated from service agencies was respect and genuine concern for their overall well-being. When considering the responses to questions 13, all research participants desired services and service providers to be respectful to them and hold no judgment of their current circumstance. Dick shared his experience upon entering a social service agency;

Dick:

“can you guys just accept me for who I am right now! Don't make me feel guilty because I spent the last 20 years using drugs and hanging out and not doing the right things. I'm still an adult. I want to be respected and I don't want no one making me feel bad, this ain't easy. I decided I want some different for my life and I need help. The question for you guys is can you help me?"

The appeal was for services and service providers to be understanding and supportive. Another participant noted that a particular social service agency had many counselors who were previous addicts and that made them understanding from her point of view. According to James;

James:

"It's kind of cool at CCC they have counselors that are former addicts and they understand what it's like and that's good for me."

Agencies that offered supportive services to houseless individuals in an atmosphere of respect, honesty was highly praised from participants. Participants expressed the need 
for service agencies to empower and encourage individuals as they attempt to leave life on the streets and they felt the support of such individual was necessary, Maximus explains;

Maximus:

"I wish someone could help me feel better about myself because it was the one thing that I could grab a hold of that made me want to get off drugs and get my own place." 
Table 5. Social Service Agency

\begin{tabular}{|c|c|}
\hline Participant & Response \\
\hline Justin & $\begin{array}{l}\text { "TPI had a 3-6-month program to help me with shelter. I had to do } \\
\text { chores, I applied at PCC and took a couple classes. I ended up } \\
\text { getting money from going to school. I didn't have skills in } \\
\text { employment so it was hard to escape houselessness. I just got my } \\
\text { grant money and my girlfriend recommended that we moved in } \\
\text { together and that is how I escaped houselessness }\end{array}$ \\
\hline Isis & $\begin{array}{l}\text { "If you go to TPI they may have shelters they can get you in while } \\
\text { they work on finding you a job and stable housing and stuff like that. } \\
\text { Central City is the same way." }\end{array}$ \\
\hline Katrina & $\begin{array}{l}\text { "I went through second chance. If you go through an eviction you } \\
\text { can take this program and then go to other landlords and say that I } \\
\text { took the program and would you rent to me. I was just by myself and } \\
\text { my daughter. I kept everything private at work so they didn't know } \\
\text { my situation no one knew I was houseless." }\end{array}$ \\
\hline Kendrick & $\begin{array}{l}\text { “The NARA Native American rehabilitation Association offered me } \\
\text { counseling they help me with applying for subsidized housing and } \\
\text { they helped me find a clinic that I could go to.” }\end{array}$ \\
\hline Willington & $\begin{array}{l}\text { "The } 8 \times 8 \text { is one of the best resources in my opinion. Its sponsored by } \\
\text { Central City Concern. I went to go work for meals on wheels and } \\
\text { they give you a debit card to keep making a couple dollars here and } \\
\text { there. Every last one of the staff at CCC are former drug addicts this } \\
\text { makes you feel like you're not alone in your struggle." }\end{array}$ \\
\hline James & $\begin{array}{l}\text { "Well I went to prison and I spent } 3.5 \text { years there. When I got out } \\
\text { they put me into transitional housing. I still live in the same building } \\
\text { that I been in since I got out of prison, I just live in the permanent } \\
\text { housing part of it. I just never left the building because of security } \\
\text { and safety." }\end{array}$ \\
\hline Chance & $\begin{array}{l}\text { "I moved into Central City Concern Housing when I got out of } \\
\text { Hoover Detox in 2013. I have been housed ever since." }\end{array}$ \\
\hline Sage & “Transitional Projects Incorporated." \\
\hline
\end{tabular}




\subsubsection{Resilience}

Resilience is defined as one's ability to utilize self-determination, social and economic capital (habitus) as a way of exiting homelessness with or without the assistance of social service agencies. Habitus is being defined as the totality of one's resources which include social capital, (i.e., education, social class, and networks) and economic capital (i.e., (money and wealth). It is the totality of one's acquired experiences and is expanded by day-to-day interactions. Table 5 includes participant responses to question 12 of 18 on the interview guide. Participants shared their reflections about the skills they used in exiting houseless. According to participants, the skills most utilize while exiting was their ability of never quitting and giving up hope. This study describes these attributes as resilience, the utility of habitus, social networks, and agency assistance. One participant described her ability to transition to housing as a survival mechanism. Sage describes it in the following way;

Sage:

“A willingness to survive, I never quit, keep trying! and I get help from my family, friends, agencies, and program that would help me. I didn't care I just wanted out”

Kendra was another research participant who couch surfed with her child, worked a full-time job, and saved money in order to return to conventional housing. For her, it was all about her mindset. Her utility of social and economic capital (habitus) was a key factor in her returning to housing stability. As Kendra explained; 
Kendra:

"Determination. Being able to accept what I could to make it. I had to take a minimum wage job. I had start from the bottom. We had a fitness membership so we went to work-out and then shower and I would go to work and my daughter went to the library every day for about 3 months. I was able to save money because I didn't have to pay rent."

Isis described the personal skills that she used while she was homeless to get her through the process of transitioning to housing stability.

Isis:

"They have to learn how to do with less so they don't need as much. They are used to going without so when they have something you don't use as much of it. Let's say food stamps for instance. Being on the streets you can't get food stamps if you have a warrant. You can't apply for them or anything because they will run your name or the paranoia that they may run your name. It's scary. That is what stops a lot of people from doing anything. The fear of going to jail. But when you get into a house and you get \$200 in food stamps, I was use to going without so I knew how to budget better."

The utility of habitus and or resilience as a way out of houselessness is highlighted by the responses of research participants when giving accounts to skills they possessed in order to gain housing stability. 
Table 6. Resilience
Question 12. As you reflect on how you made the transition, what factors about yourself or skills you have help you move from a life off the streets?
Resilience (as an exit strategy)

Participant
Response
Vera
"You have to be able to look at things and not really see things as
being the only way and that they never change. And just knowing it
was temporary. I made it fun for my kids because they were young
enough but I knew that they would probably not remember. So, I
made sure to think of things like when we would be in a hotel I
would say this is how it is gonna be when momma gets rich we will
stay in hotels watching movies and cartoons swimming in the pool
having room service and not have to clean the room or make your
beds. I just made it fun for my kids I never let them think this was
permanent."
"Determination. Being able to accept what I could to make it. I had
to take a minimum wage job. I had start from the bottom. We had a
fitness membership so we went to work-out and then shower and I
would go to work and my daughter went to the library every day for
about 3 months. I was able to save money because I didn't have to
pay rent."

Thelma "Unconditional love. I learned to be compassionate, kind, very respectful and set boundaries. Feeling the pain of others which would result in more pain in me. I had to learn to be more open minded."

Dick "The ability to make it man. The ability to make it."

Maximus "The one thing I would say is a negative thing about it because I have been homeless before and for so long and so many times, I am not afraid of it. You know what I mean? like my world could crumble down around me and I know that I can pick myself back up because I have before. I am not afraid of it."

Willington "I learned things about myself when I was homeless that I did not know that I could do, I have this amazing like determination to where when I set a goal it's gonna be accomplished no matter how I go about accomplishing that goal, it is going to get done. I attribute it to the fact that I lived this certain lifestyle for so long and I supported that lifestyle for so long no matter what. When I decided to change my life around, it was like I can do this, I just have to put my mind to it and figure it out and get it done." 


\subsubsection{Feelings of Achieving Housing Stability}

In this section, participants share their feelings of achieving housing stability and how they felt after reaching their goal. They shared feeling of happiness, joy, selfsatisfaction and peace brought on by the experience of transitioning into conventional housing. This table provided participants the opportunity to reflect in their own words on the time when they received the keys to their home. This is the goal, the end of the journey: the return to conventional housing. Justin had tears in his eyes as he exclaimed what obtaining housing meant to him, Justin:

\section{“Everything!”}

Another participant proclaimed with a big smile,

Thelma:

\section{"Fantastic"}

James explained his thoughts and feelings of having keys to his place:

James:

"For me stability is such a huge; it has a huge effect on my life. And if I am stable, everything else can just fall. You know what I mean? Like that is my main goal in the world is to be stable on my own, because I wasn't for so long, so for me it's huge. Its huge for me, it really, really is, I mean no matter what color the house is, where its located, its ours. My daughter moved in now, you know what I mean, like it's just huge, it's huge."

Chance sat in her seat smiling and pronounced:

Chance:

"There was no better feeling that holding those keys in my had. I did it I really did it". 
Maximus:

"I felt like superman for that moment I was invincible."

Thelma:

"So grateful so grateful".

Dick:

“I thought I was dreaming I couldn't believe it”.

Participants shared feelings of safety, happiness, and shared feelings of peace as a result of gaining housing stability. Isis shared her feelings,

Isis:

"Yeah it's the security. It's not a safety as in I am gonna get hurt or anything. It's just a personal security. That's what it's all about. To this day, I like to do things my own time. For years, it's like they want the dishes done or they want the house clean. If I want to go to bed and there are dishes in the sink, it's my house and I can do that. If I want to step out of the bathtub and shake my head and get the walls wet, I can do that. But whenever you are dealing with someone else mood swings and someone else's issues and if you add drugs to it to it just makes things 100 times worse”. 
Table 7. Feelings of Achieving Housing Stability

Question 19. How do you feel you know that you have a place to call home? Feelings of Achieving Housing Stability (feelings after achieving housing stability)

\begin{tabular}{ll} 
Participant & \multicolumn{1}{c}{ Response } \\
\hline Sage & "Having a place to live, I guess it fits, its centering in a way." \\
Maximus & $\begin{array}{l}\text { "Like I don't have to worry when I get off work where I am going to } \\
\text { go sleep at night, you know what I mean? I don't have to worry if I } \\
\text { am going to get woken up by the cops in the morning. You know what } \\
\text { I mean? I get to wake up in my bed every day." }\end{array}$
\end{tabular}

Katrina "If I had to sum it all up in one word, I would say blessed. I am so grateful that there are programs out there that do help."

Dick “It doesn't feel like home. The idea having a home is still odd. I am use to being homeless and being active, I feel spoiled."

Isis "Happy! Safe and secure! I am a cancer so I have to have a home. I mean I always said that so as long as I have my house, everything else can fall apart around me. I have a place to go!

Chance "It feels really good! I can just go home to my own place and try to get my life back where I can do God's will instead of living house to house. I don't want to be like that. I try to keep my next move my best move and try to do what I can to keep things right. People helped me and I thank God for what people have done to help me."

James "For me stability is such a huge; it has a huge effect on my life. And if I am stable, everything else can just fall. You know what I mean? Like that is my main goal in the world is to be stable on my own, because I wasn't for so long, so for me it's huge. Its huge for me, it really, really is, I mean no matter what color the house is, where its located, its ours. My daughter moved in now, you know what I mean, like it's just huge, it's huge."

Lexus "I love it. I feel good to have a key open up, lay down, turn the TV on and relax.

Kendrick "I still feel hungry, Life is a journey and I appreciate that I came from the actual bottom and work my way up. Life is beautiful like that." 


\subsubsection{Change in Social Networks}

Once participants received their keys they became aware that they had to change their social networks in order to remain clean and sober and in conventional housing. Participants responded to questions about the change that they experienced in their social networks. Participants reported that they experienced changes in their social networks and indicated a need to distance themselves. One participant responded by disassociating herself with currently houseless individuals. Vera reported, Vera:

"I just say hi and move out of the way. I don't want relationships with them but I respect them."

Katrina explained,

Katrina:

"Now I am clean and sober I changed the people I hang out with I had to, I wanted to stay clean and sober."

Chance expressed,

Chance:

"Yes, I do. I stop and I have a brief talk with them but in order for them to change their situation, they have to want it. I am not going backwards and they see that I am serious in my recovery."

Comments such as these were prevalent throughout this research and participants felt the only way they could stay in housing and remain clean and sober was to change their friends and associates. The following exchange between the researcher and participant is indicative of this shift in relationships and his new self-image. 
Interviewer:

"Do you still stay in contact with people who are homeless?”

Maximus:

"Yes, limited contact. I am not going to put myself at risk."

Interviewer:

"Risk of what?"

Maximus:

"Like there are people that I love with all my heart that mean so much to me in my life and what I have become today probably wouldn't have happened without their influence in my life, but they are still not doing anything positive, still doing the same thing, same thing over and over."

Interviewer:

"What is that same thing?"

Maximus:

"Drugs, running amuck, and committing crimes and things like that. And I will say hi to them on Facebook, I mean I might even hug them as I pass them walking on the street, but I am not going to stay. If you go to a barber shop, you're getting your haircut, you know what I mean? You are not going to stay. I am not going to sit there, I am not going to say, 'Oh, I love you,' and continue and the majority of the people in my life that I feel that way about respect it. Like they get it, especially when they see me happy, doing good, and something different."

Overwhelmingly, research participants changed their social networks as a result of obtaining housing stability and their desire to live a clean and sober life. They became more guarded regarding their return to conventional housing. Participants choose to 
distance themselves but still remain in contact with currently houseless individuals they limit the amount and proximity of contact.

Table 8. Change in Social Networks

Question 16. Do you still have contact with people who are houseless? (Social Networks) If so what kind of contact? (Friends / Financial Support / Mentors) (Why or why not?)

Change in Social Networks (after achieving housing stability)

\section{Participant}

Isis

Dick

Justin

Willington

James

Kendrick

Vera
"Some of them were my good friends but since I stopped using drugs, I don't have contact with them anymore because I don't use drugs anymore."

"Yes, I do. I stop and I have a brief talk with them but in order for them to change their situation, they have to want it. I am not going backwards and they see that I am serious in my recovery."

"The people that I hang out with now have their job, go to church, keep God first. I go to NA and AA meetings. All positive things. I had to change the people I hang out with."

"Just a simple hi. My relationship is distant because I don't see any willingness on their end. I give them mentally stability only"

"I had to if I want to stay in my place and clean and sober I had to"

"It took me too long to get her and I am not gonna miss this opportunity for anybody. I love my homeless friends but I love me more."

“I will always be a part of the community, I just can't be the community I have to think what is best for me and my children." 


\subsubsection{New Identity}

The emergence of a new self-image is the last of the emergent themes for this study. Research participants experienced the desire to change social networks as a result of gaining housing stability. They also experienced changes to their self-image, and they were no longer willing to take risks in their personal life for the sake of their friends who chose to remain living life on the streets. Table 8 captures some elements of that theme. For example, Thelma explained,

Thelma:

"I can see that they have that respect and it's a good feeling to be around."

James described it in the following way, James:

"They tell me that I am a new person. I can see that they have respect for me and it's a good feeling to be around."

Thelma's new self-image is gaining her respect among her peers. She is happy and feeling good about herself and her decision to return to conventional housing. James is experiencing similar feelings from his peers and he also is pleased with the outcome of his decision to return to conventional housing. The individual choices to return to housing stability varied from participant to participant; however, no participant in this study regretted making the decision to achieve housing stability. All participants expressed feelings of happiness and gratitude for the individuals that help them transition to conventional housing. 
As the individuals narrative accounts of the experiences of exiting houselessness evolved, one participant's comment summarizes a universal need for housing Vera stated,

Vera:

"I believe that everyone deserves to live in a home. There is no reason for anyone to be homeless. It is a violation of our human rights to have a dog living indoors and have a family living outside." 
Table 9. New Identity
Question 17. Tell me about the people you hang out with now that you are housed? (Social Networks)
New Identity (after achieving housing stability)

Participant Response

Chance "I am thinking about going to school, get me a job to get further in my life. I stay fully focused."

Sage "The people I hang out with are mostly previously homeless they are like my best friends in the whole entire world, one of them just got a year clean living, he is living at City Team right now, working two different jobs, doing great, and that's somebody you would never think could ever have come off the streets."

Maximus I I hang out with my friend that is clean and sober who was one of my drinking partners 20 years ago and we build each other up.”

Isis "I wouldn't hesitate to like be the type of people who pass out socks down here, or like food down here. I would love to do stuff like that. As long as I am doing it on the go, hitting the little spots and continue going. I want to support that change in me."

Vera "I will come across times when like special people in my life will go to treatment and I will drop everything I have going on to go buy them some wife beaters, boxers, and socks and drop it by like way out of my way at a place I don't even like to go just to take them this stuff to be supportive of them. I will always, if somebody wants to do something different and I have known you from the past, I will always do whatever I can to support that. I have gotten several people jobs through this company; you know what I mean, like I will be there. But if you are not going to do nothing different, it's got to be that, "hi, love you, bye," it's got to, it's got to." 


\section{CHAPTER 6 \\ DISCUSSION}

The findings of this study highlight the process associated with exiting houselessness as described by 12 formerly houseless individuals. These findings support previous research and bring insight into the various aspects involved in the process of achieving housing stability. Participants identify a variety of events and circumstances that led to transitioning from life off the streets into housing stability. The findings of this study suggest that the process of exiting is made up of several steps or levels of various activities that facilitated such exits. These steps are not mutually exclusive, nor are they meant to portray a linear path in the exiting process. Participants shared similar exit strategies which fell into three distinct exit routes which I named mega themes: 1) Social Service Agencies, 2) Exposure to Criminal Justice System 3), and Leveraged Social Capital/Habitus. Individual narrative responses of houseless exits fell into seven sequential steps, which I have highlighted as the emergent themes of this research study. The emergent themes are as follows: (1) My Mind's Made Up; (2) Social Networks; (3) Social Service; (4) Resilience; (5) Feelings of Achieving Housing Stability; (6) Change in Social Networks; and (7) New Identity.

\subsection{Exit Strategies}

The exit strategies utilized by the 12 participants in this research are affirmed in literature regarding the ways in which individuals exit houselessness (Reitzes et al., 2003; Cheng et al., 2013; Anon n.d. Anon 2003).

While the circumstances and events associated with exiting houselessness differed for each participant it was possible to identify factors, events, and experiences that led to 
successful transitions. The need for affordable and appropriate housing is crucial in the process of exiting, and it is the number one cause of individuals who experience houselessness (Abbott, 2008; Caton, C.L., et al., 2005; Cheng, Tessa et al., 2013; Clarren, 2005; Karabanow, 2008; Rollins, Chiquita et al., 2012; Shelton, K.H., et al.,2009).

In this section, we find possible answers to research question number two; however, it will be fully explored in the following discussion of the emergent themes.

\subsubsection{My Mind's Made Up}

Participants often identify a pivotal event that led to their decision to exit houselessness. This decision was caused by a myriad of incidences in the lives of participants, be it incarceration, a dramatic life experience such as a death, or a personal loss, or simply being tired of living life on the streets. For some participants, it was the desire to live a clean and sober life while others wanted to have good relations with family members and friends. One research participant saw his future and the prospects of it, made him decide to stop using drugs and get into stable housing. Participants experienced changes in their motivation and this followed a generally consistent pattern: they became disenchanted with living life on the streets, followed by focusing on the decision to find permanent housing. Chance stated:

Chance:

"The amount of effort I put into making sure I had money for drugs every day is the same amount of energy I used when I decided to leave the streets. I was just done I wanted something new, something different, something more." 
This is an important concept because it requires an individual to be tired of their circumstance and to hold a desire for a different, more fulfilling life - and often times a clean and sober life. This reaction supports the notion that transitioning from houselessness to conventional housing can serve as a catalyst and platform which will aid individuals in their recovery (Tsemberis et al., 2012).

\subsubsection{Social Networks}

The findings of this study are in line with current literature. Individuals in my study interacted within their social networks transferring information from one party to another. Family networks can sometimes be problematic to individuals as a result the concept of family is redefined to include two additional, often overlapping networks: close friend networks and non-kin networks.

Houseless individuals also redefine the use of community. The family of houseless individuals refer to one another and family living in one large community the place they call home. Community is essential to this population as they are often times abandoned by their families and the integration in their community is essential to their sense of worth and esteem. The community provides a sense of belonging. Anyone is welcome and once you are a part of this community you are always welcome.

The learning/socialization that takes place among houseless individuals forms bonds that soften times supersede familial relationships. As a way of coping with life on the streets information is transferred from person to person and group to group, serving as a pathway of knowledge transfer between individuals.

According to the literature, houseless individuals have networks they utilize for social support. The first research question sought to answer the salience of these networks. 
By understanding that houseless individuals share knowledge about various resources as well as information about programs that aid individuals in exiting.

\subsubsection{Social Services}

There was an overwhelming sense of gratitude from participants to agency providers who aided them in their exits. They equated their happiness and drug free living to the individuals who work at these facilities. The presence of social service agencies which support houseless individuals by providing aid in the areas of health, employment and housing is a key factor in determining successful exits. Participants affirmed the value of programs that aid individuals in substance abuse treatment, and employment and training services. Once a participant was connected to an agency they felt reasonably assured about obtaining housing. They knew that when they were ready services were available to aid them. This information was commonly shared among participants providing evidence about the ways in which information is transferred among houseless individuals. The presence of staff who have had some of the experiences of houselessness also increased the level of comfort in using such services. One participant noted that many of the counselors at one agency were all recovered addicts, which made her feel at ease when she was in counseling for her addiction.

The second research question sought to answer what are the resources that houseless individuals utilize. Nine of twelve research participants leveraged agency assistance to exit houselessness. Agency assistance in exiting is necessary for a large part of the population of houseless individuals. By offering services that address the ever-changing needs of this population social service agencies are making a positive impact. The ability to make a successful transition is influenced by access to institutional and social networks 
Participants utilize the services from the following agencies: Central City Concern (CCC) and Transitional Projects Incorporated (TPI), Veterans Administration Supportive Housing (VASH), Home Forward, and NARA Native American Rehabilitation Association individuals, when they are ready they will be able to return to housing stability.

\subsubsection{Resilience}

In this research, resilience is defined as one's ability to utilize self-determination, social and economic capital (habitus) as a way of exiting homelessness with or without the assistance of social service agencies. Habitus is being defined as the totality of one's resources which include social capital, (i.e., education, social class, and networks) economic capital (i.e., (money and wealth), it is the totality of acquired experiences, and is expanded by day-to-day interactions. The questions surrounding the utility of resilience were designed as a way of understanding how individuals exit houselessness based purely on their ability to utilize resilience. I use resilience to describe independent exits (individuals who exited without agency assistance), and participants making dependent exits (individuals who relied on supportive services) also exhibited resilience. These individuals relied on social capital as a way of gaining housing stability through a positive mindset or "hustling skills." As one participant noted. Individuals were able to use forms of social capital such as; employment opportunities, housing, medical treatment centers, and rehabilitation programs through houseless networks and associations as a pathway out of houselessness.

Three research participants who had independently exited houselessness were couch surfers. These participants exhibited resilience, which is the utility of social and economic capital by working while houseless. Economic Capital for houseless 
Individuals is there knowledge, it is view as an economic resource. Individuals who couch surf have different social networks than do individuals living on the streets. Four of my participants shared common traits: they worked full-time jobs, they were all women, mothers, and they kept their state of the houselessness a secret to co-workers. This coincides with literature regarding women, and poverty (Wong and Piliavin 1997). The desire to return to housing stability from a person who is currently experiencing houselessness exhibits resilience and habitus irrespective of independent or dependent exits.

\subsubsection{Feelings of Achieving Housing Stability}

In this section participants share how the experience of achieving housing stability made them feel. Finally, my keys symbolize the accomplishment of returning to conventional housing. One participant stated that they "felt human again", as if she had been reborn the moment she was given the key to her new home. I reflected upon the time that I, too, received the keys to my home. It made me feel alive. I wrote this research question as a way of understanding as if that moment was shared in commonality with others who were receiving the keys to their homes. To gain a greater understanding of the feelings that are experienced by individuals as they exit houselessness is the focus of this study. Responses from research participants were feelings of satisfaction, security, safety, happiness, and stability. One participant shares his feeling of achieving housing stability in one word he said "Everything."

\subsubsection{Changes in Social Networks}

After achieving housing stability nine of twelve participants came to the realization that they would have to change their social relationships. Nine out of twelve participants 
reported significant changes in their peer group affiliations. The same nine out of twelve participants reported they would limit contact with currently houseless persons, because they perceived them to be a threat to their new life-choices. The remaining three participants who did not experience changes in their social networks were couch surfers and are not connected to a network of houseless individuals who live life on the streets. The changes in social networks are concurrent with the establishing of a new identity once individuals gained housing stability. Participants appeared more mindful of their vulnerability to houselessness in the findings. I note a dialogue between myself and a participant as he shared his experience of gaining housing stability and his unwillingness to continue relationships with individuals who are currently houseless and continue to use drugs and participate in illegal activities.to street life especially, if they maintained their old social networks.

\subsubsection{New identity}

At the time that participants achieved housing stability, they all reported experiencing positive changes in their identity such as a desire to living a clean and sober life, connecting with a higher power. Eight out of twelve participants started attending groups meetings in an effort to make their changes long-lasting such as Alcoholics Anonymous, Narcotics Anonymous, and Smart Recovery. Participants described increased levels of happiness and self-esteem at having accomplished their goal of housing stability. All twelve participants spoke of the experiences of returning to conventional housing as empowering. All participants reported experiencing higher levels of self-worth self-preservation. Eight out of twelve participants reported increased levels of respect from their currently houseless peers. Six out of twelve participants spoke of future plans such as school, employment, and renewing 
relationships with family. Participants reported that embracing their new identity had challenges such as changes in daily routines, establishing new networks, and discovering the need to change social networks.

All participants are more protective of themselves and are unwilling to place themselves in a vulnerable position by associating actively with currently houseless individuals who are either engaging in criminal activity or drinking and using drugs.

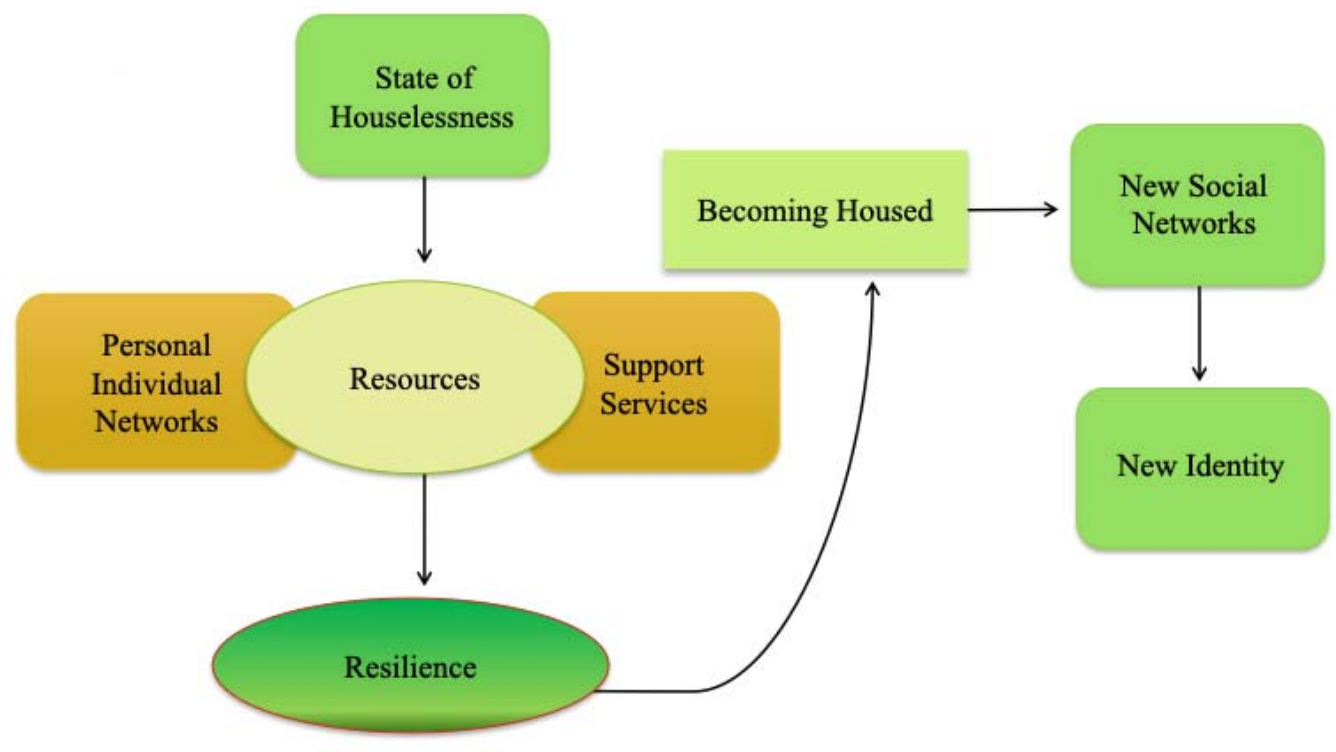

Figure1. Conceptual Framework for Transition

Figure 1 above serves as a conceptual map of the pathways that participants took to transition out of houselessness. There is a myriad of reasons why and how people become homeless but this is not the focus of this study. The conceptual map begins at the point of homelessness and describes how people transition and the conditions and resources facilitate that transition. 


\subsection{Resources}

Participants who had reached a point where they became tired of living on the streets and wanted to make a change are able to leverage the knowledge they had acquired about resources that aid houseless individuals in exiting houselessness. It was at that point that they were able to utilize resources about housing that had been offered to them time and time again. One important factor that needs to be highlighted is that "couch surfers" because of their unique houseless status of living in other peoples' homes are not eligible, or given the same opportunity, to utilize agency resources as readily. That population relies instead on family and friends to begin the journey of exiting houselessness. The diagram captures these two kinds of resource support.

\section{Support Agencies}

Social service agencies help with a plethora of issues that houseless individuals face on a day to day basis. Many social service agencies in the greater Portland area offer support services such as mental health counseling, drug and alcohol treatment programs, housing, temporary shelters, employment opportunities, food, and educational opportunities. These supports assist houseless individuals in regaining their self-esteem and self-awareness. As self-affirming supports they aid individuals in returning successfully into conventional housing.

\subsubsection{Personal Networks}

Unlike other houseless individuals, couch surfers rely on personal networks for housing as one avenue of maneuvering, while being houseless. All individuals turn to their casual acquaintances or other connections to learn about key resources that can help them. This is similar to what Granovetter describes as "the strength of weak ties." 


\subsubsection{Resilience}

Resilience is defined as one's ability to utilize self-determination, social and economic capital to craft a way of exiting homelessness with or without the assistance of social service agencies. By relying on the kind of self-affirming support received from social service agencies combined with valuable information from personal networks, individuals are able to build a resilience which creates a desire, and an internal strength in themselves which facilitates a path to conventional housing.

Becoming Housed: Feeling of Achieving Housing Stability

Gaining housing stability had a profound impact on participants. Many spoke of the feeling of accomplishment and self-satisfaction that they experience as a result of becoming housed. This point of achievement was very pronounced and stands out as a key marker in the process.

\subsubsection{Social Networks Post Transition}

Social networks shift and change as a result of gaining housing stability. Participants spoke of the need to protect themselves and their new life decisions to live a clean, drug free life no longer tied to the ills of houselessness. They spoke instead of the value of forming new social networks that they associate with living and participating in a working society. When the shift in housing stability takes place, there are several other areas of individuals lives that fall into sequential order. The first one is about identity and the second, the change in personal networks and friends. Participants spoke of their currently houseless friends with great fondness but they make very clear statements of the need to protect their newly found freedoms with the change in social networks. 


\subsubsection{New Identity}

A pattern of speaking of a new identity by participants who have recently been housed was apparent. Participants became careful of their achievement of obtaining housing stability, sobriety, and increased levels of self-esteem. No longer living life in a fragment of society but seeing themselves as a contributor. The process of exiting houselessness gave participants a renewed sense of self-worth.

Coming full circle, we note the research questions:

1. What social factors and experiences, as reported by research participants, influence their ability to move into conventional housing?

2. What are the resources and support services used by those who successfully transition into conventional housing?

This study employed two theoretical frameworks (Habitus; Bourdieu, 1977: Wacquant, 2011) and (Strength of Weak Ties; Granovetter, 1983) to explore the social factors and conditions that enable houseless individuals to transition into conventional housing. It relied on narratives developed from interviews with 12 formerly houseless individuals and a grounded theoretical approach to uncover the processes, connections, and conditions that facilitate transitions out of houselessness. These conditions include access to institutional support that was provided from a variety of entry points ranging from contact with the criminal justice system, drug and alcohol programs, social service agencies; and access to social network supports that was facilitated primarily via family, friends, and acquaintances that leverage social capital. 


\section{CHAPTER 7 \\ REFLECTION AND CONCLUSION}

I studied the qualitative accounts of twelve individuals who exited houselessness in Portland, Oregon, to address two research questions:

1. What social factors and experiences as reported by research participants influence their ability to move into conventional housing, and

2. what are the sources and support services used by those who successfully transitioned into conventional housing?

The aim of the study was to give voice to individuals who have been uninvited to the table when addressing the needs of houseless persons in their pursuit to gain housing stability.

The individual exits from houselessness categorized in emergent themes were: (1) My Mind's Made Up; (2) Social Networks; (3) Social Service; (4) Resilience; (5) Feelings of Achieving Housing Stability; (6) Change in Social Networks; and (7) New Identity. The classification of these themes developed through analysis revealed how participants exited houselessness in a multiplicity of ways. The emergent themes are phases that each participant encountered in their process of exiting. From the data analysis, a sequential order was established for the emergent themes. This is highlighted in the findings and expanded upon the discussion section. 
This study adds to the existing body of knowledge sociological research by:

1. Increasing the knowledge of transitions out of houselessness as told from the perspectives of the individuals that have done so

2. Examining narrative accounts to gain a different perspective of the needs of individuals as they exit

3. Exploring the individual accounts of exiting that offer insights into the design of programs that may aid individuals as they transition

There are three areas of the study that are worthy of note and reflection: the significant amount of racial/ethnic diversity in the pool of participants; the different understandings of success by participants; and the policy implications of this work.

\subsection{Racial Disparities in Houseless Individuals}

Although race was not a focus of this study, it is imperative to mention the substantial presence of racial diversity among the participants. It was an unintended outcome and it warrants acknowledgement and discussion. Racial minorities are overrepresented in lower socio-economic classes, lower education achievement, higher unemployment rates, and higher rates of health-related issues per capita (U.S. Census Bureau, 2019). According to Jennings, racial minorities are also overrepresented in populations of houseless persons nationwide. (Jennings, L., Shore, D., Strohminger, N., \& Allison, B. 2015).

A possible reason for the degree of diversity in my study, may be in the sampling technique. This study employed snowball sampling technique to identify participants. Houseless racial minorities tend to live in proximity of one another and keep network 
connections. Having started with an informant who was from a racial minority it was then very likely that following participants would also be people of color.

\subsection{Understandings of Success}

In the process of the interviews, participants often referred to the word "success." It became apparent that they used it with a variety of meanings. Success for some individuals is using services as a resource when they are in need and have no desire to return to conventional housing. For others, success is integration into conventional housing and living in mainstream society. For couch surfers, housing success may be a living situation where their name is on the lease agreement giving them direct influence over their housing. The levels of success are as diverse as the population. This research focuses on the definition of success as described by research participants.

\subsection{Policy Implications}

The research questionnaire asked participants for recommendations for possible programs that they believe in retrospect would have aided their transitions. The results of this inquiry are highlighted in six major areas: (1) better communication and outreach to the couch surfing community; (2) remove punitive measures from programs that prohibit access for houseless individuals to services such as food stamps, housing, employment and counseling; (3) remove the "one strike and you out" restrictions from service providers; (4) relocate housing units for newly placed houseless persons; (5) treating houseless persons with dignity by providing access to the commons (6) creating programs that would aid in their ability to restore self-esteem and self-worth. (7) culturally appropriate service supports programs that honor diversity and celebrate the human condition 
Of the participants who "couch surfed," three out of twelve felt as though they were an overlooked part of efforts to support the houselessness, and they felt that programs should be designed to address their particular needs are for better communication and outreach. They are not connected to the community of houseless individuals and often times are unaware of programs which might assist them in finding housing or other resources such as housing vouchers, employment, medical services and counseling. Seven out of twelve participants desired programs that would allow them to obtain food stamps, housing, medical treatment and counseling without the risk of jail and/or imprisonment. Seven out of twelve participants shared their apprehensions and lack of trust in utilizing social service providers, fearing that they may report them to local authorities. According to Sean Kidd these apprehensions are common among houseless individuals (Kidd, S.A., 2013).

Six out of twelve participants felt that housing centers should allow individuals more than one chance for assistance programs. Agencies need to understand that returning to housing can be difficult and the pathway are not straight and that individuals may relapse. There are circumstances that derail even the best of intentions and patience should be a part of that journey for service providers.

Nine out of twelve participants struggled to cut ties with street cultures once they had obtained housing. Units that house new residents should be located away from known area of densely populated houseless communities. Three participants reported recidivism due to the close proximity of the street life.

All participants desired access to basic needs i.e. food, housing, public restrooms, and showers facilities. They share a desire for local authorities to be sympathetic to the struggles of houselessness by treating them like human beings. 
Lastly participants shared a common desire for programs that aid in their ability to restore self-esteem and self-worth. According to research when individuals have increased levels of self-esteem they are more likely to exit houselessness and have lower chances of recidivism (Biswas-Diener, Diener, 2006; Kidd S.A., 2008; Molina, 2000).

\subsection{Limitations}

The scope of this study is limited in that it is not a representative sample and not generalizable to the overall population of houseless individuals in the city of Portland. It focuses on the narratives and experiences of a small segment of this population. As the researcher with a personal past history of houselessness, I bring my own set of experiences and biases to this project. It is difficult to know how much I influenced outcomes considering my past experiences with houselessness. Additionally, focusing exclusively on the population of houseless persons in the city of Portland, this study would not be representative of the total population of houseless persons in the country and the validity is limited in scope and utility on a larger scale. In the utilization of qualitative interviews, reliability is not achievable in that it focuses on the deep rich descriptions found in the lived experiences of formerly houseless individuals

\subsection{Future Directions}

This thesis focused on the individual narratives as they exited houselessness. The number of individuals who experience houselessness is rising with racial minorities in the forefront as noted earlier. Racial minorities experience homeless at rates that are more than their represented numbers in the overall population. Further study of racism and the impacts to these individuals is of dire need. In the city of Portland, Oregon hate 
crimes increased $200 \%$ since the election of the 45 th president of the United States (U.S. Department of Justice, 2016). A study of the effects of racism, as a barrier to exiting houselessness may prove beneficial to our understanding of this social problem. Many factors intersecting with houselessness require focused study, factors such as individuals who are houseless with mental problems, drug dependency, LGBTQ and gender. Sociological study should continue in this field until housing stability is achieved. 


\section{REFERENCES}

Abbott, C. (2008). Voices From The Street: Truths About Homelessness From Sisters Of The Road. Oregon Historical Quarterly 109(1):153-55

Anderson, D.G., \& Rayens, M.K. (2004). Factors influencing homelessness in women. Public Health Nursing, 21: 12-23

Allen, K., (2011). Social Lens: An Invitation to Social and Sociological Theory: $2^{\text {nd }}$ Edition. Greensboro, North Carolina. 120-125

Bantchevska, D., Bartie-Haring, S., Dashora, P., Giebova, T., \& Slesnick, N. (2008). Problem behaviors of homeless youth: A social capital perspective. Journal of Human Ecology, 23: 285-293

Bao, W.N., Whitbeck, L.B., \& Hoyt, D.R. (2000). Abuse, support, and depression among homeless and runaway adolescents. Journal of Health and Social Behavior, 41: 408-420.

Biswas-Diener, R., \& Diener, E. (2006). The subjective well- being of the homeless, and lessons for happiness. Social Indicators Research, 76: 185-205.

Bender, K. (2007). Capacity for Survival: Exploring Strengths of Homeless Street Youth. Child \& youth care forum, 36 (1): 25

Beatty, J. W. (1985). Street Kids: Children in Danger. Retrieved July 19, 2014 $<$ http://www.worldcat.org/oclc/425691318>

Blake, E. (2013). Boomtown charity buys homeless one-way ticket out. CNN Wire, Jan 11, 2013

Bourdieu, P. (1984). Distinction: A Social Critique of the Judgement of Taste. Massachussets; Harvard University Press, Print

Bourdieu, P. (1986) The forms of capital. In J. Richardson (Ed.) Handbook of Theory and Research for the Sociology of Education (New York, Greenwood), 241258

Bourdieu, P. Sociology in Question. 1994. Print

Boyd, D. \& Ellison, N. (2008) Social Network sites: Definition, History and Scholarship. Journal of Computer-Mediated Communication. 13(1): 210-230

Burt, M. R. (1992). Over the Edge: The Growth of Homelessness in the 1980s. New York and Washington, Russell Sage Foundation and The Urban Institute Press

Burt, M. R., and Cohen, B. E. (1989). Differences among homeless single women, women with children, and single men. Social Problems. 36:508-523 
Campbell, J. P. (2012). Subsistence Strategies of Homeless LGBTQ Youth in Portland, Oregon. Retrieved July 19, 2014

$<$ http://www.worldcat.org/oclc/859547520>

Caton, C. L., Dominguez, B., Schanzer, B., Hasin, D. S., Shrout, P. E., Felix, A., McQuiston, H., Opler, L. \& Hsu, E. (2005). Risk factors for long-term homelessness: Findings from a longitudinal study of first-time homeless single adults. American journal of public health, 95(10): 1753-1759

Cheng, T., Wood, E., Feng, C., Mathias, S., Montaner, J., Kerr, T., \& DeBeck, K. (2013). Transitions into and out of homelessness among street-involved youth in a Canadian setting. Health \& Place, 23: 122-127

Chamberlain, C., and Johnson G., (2013). Pathways into Adult Homelessness. Journal of Sociology 49 (1): $60-77$

Charmaz, Kathy. (2006). Constructing Grounded Theory: A Practical Guide through Qualitative Analysis. London: Sage Publications

Choca, M. J., Minoff, J., Angene, L., Byrnes, M., Kenneally, L., Norris, D., ... \& Rivers, M. M. (2004). Can't do it alone: housing collaborations to improve foster youth outcomes. Child Welfare, 83(5).

Clarren, R. (2005). The Village That Shopping Carts Built: An Initiative by the Homeless Challenges Society on Sustainability. Orion Magazine. 24(1): 7677.

Clarke, G. N. et al. (2000). Psychiatric Hospitalizations, Arrests, Emergency Room Visits, and Homelessness of Clients with Serious and Persistent Mental Illness: Findings from a Randomized Trial of Two ACT Programs vs. Usual Care. Mental Health Services Research. 2(3): 155 - 64.

Cohen, Judith A (2002). Treating Traumatized Children: Clinical Implications of the Psychobiology of PTSD. Trauma, Violence \& Abuse. (1524-8380), 3(2): 91

Cuti, J. R. (2005). Homelessness Is Not A Crime. Just Out. 22(24):16 - 17

Decker, S., Cary, P., \& Krautscheid, L. (2006). From the Streets to Assisted Living: Perceptions of a Vulnerable Population. Journal Of Psychosocial Nursing and Mental Health Services. 44(6): 18 - 27

Choca, M. J., Minoff, J., Angene, L., Byrnes, M., Kenneally, L., Norris, D., Pearn, D., \& Rivers, M. M. (2004). Can't do it alone: housing collaborations to improve foster youth outcomes. Child welfare. 83(5): 469 - 492

Dachner, N., \& Tarasuk, V. (2002). Homeless 'squeegee kids': Food insecurity and daily survival. Social Science and Medicine, 54: 1039 - 1049. 
Department of Housing and Urban Development Federal Register/Vol. 80, No. 233/Friday, December 4, 2015/Rules and Regulations 75791

De Rosa, C. J., Montgomery, S. B., Kipke, M. D., Iverson, E., Ma, J. L., \& Unger, J. B. (1999). Service utilization among homeless and runaway youth in Los Angeles, California: Rates and reasons. Journal of Adolescent Health, 24(3): $190-200$

Diener, E. (1994). Assessing subjective well-being: Progress and opportunities. Social Indicators Research, 31(2), 103

Diener, E., Napa-Scollon, C. K., Oishi, S., Dzokoto, V., \& Suh, E. M. (2000). Positivity and the construction of life satisfaction judgments: Global happiness is not the sum of its parts. Journal of Happiness Studies, 1(2): 159 - 176.

Diener, E., \& Seligman, M.E.P. (2002). Very happy people. Psychological Science, 13: $80-83$

Dorsen, C, (2010). Vulnerability In Homeless Adolescents: Concept Analysis. Journal of advanced nursing (0309-2402), 66 (12): 2819.

Dworkin, A. (2007). A Hand to the Homeless, from One Who Knows. Oregonian, The (Portland, OR).

Dyb, E., (2009). Imprisonment: a major gateway to homelessness. Housing studies, 24 (6): 809_824.

Edelbrock, C. (1980). Running away from home: Incidence and correlates among children and youth referred for mental health services. Journal of Family Issues, 1: 210-228.

Ensign, J. (1998). Health issues of homeless youth. Journal of Social Distress and the Homeless, 7(3): 159-171.

Erdem, G, (2010). That Which Does Not Kill You Makes You Stronger: Runaway Youth's Resilience to Depression in the Family Context. American journal of orthopsychiatry (0002-9432), 80 (2): 195.

Foscarinis M. (2014). Homeless problem bigger than our leaders think: Column, USA Today, Jan. 16, 2014

Frey, W. H. (2014). Diversity explosion: How new racial demographics are remaking America. Brookings Institution Press. 
Goldstein, A. (2007). "A place of my own”. Homeless families in the New York City shelter system: The long-term stayers. A comparative study of homeless families headed by women. City University of New York.

Granovetter, M. (1983). The Strength of Weak Ties: A Network Theory Revisited. Sociological Theory, 1: 201-233

Granovetter, Mark S. The Strength of Weak Ties. American Journal of Sociology, 78(6): $360-1380$

Grenfell, M. (2008). Pierre Bourdieu: Key Concepts. Durham: Acumen Publishing Limited.

Greene, T. W. (2012). A Paradox Of Street Survival: Street Masteries Influencing Runaways' Motivations to Maintain Street Life. Theory in Action, 5(3): 31-57.

Hiscock, E., Wilks, N., Stafford, M., Joseph, M., \& Lemin, R. (2008). Exit this way: young people transitioning out of homelessness. Social Alternatives, 27(1): 65.

Hopper, K., Shinn, M., Laska, E., Meisner, M., \& Wanderling, J. (2008). Estimating numbers of unsheltered homeless people through plant-capture and postcount survey methods. American Journal of Public Health, 98(8): 1438-1442.

Interagency Council on Homelessness: Notice of Funding Availability (NOFA) for the Collaborative Initiative to Help End Chronic Homelessness. Federal Register [Docket No. FR-4805-N-01] January 27, 2003.

Jennings, L., Shore, D., Strohminger, N., \& Allison, B. (2015). Entrepreneurial development for U.S. minority homeless and unstably housed youth: A qualitative inquiry on value, barriers, and impact on health. Children and Youth Services Review, 49(5): 39-47.

Karabanow, J. (2003). Creating a culture of hope: Lessons from street children agencies in Canada and Guatemala. International Social Work, 46(3): 369386.

Karabanow, J. (2004). Being young and homeless: Understanding how youth enter and exit street life. New York: Peter Lang.

Karabanow, J. (2008). Getting off the Street: Exploring the Processes of Young People's Street Exits. The American behavioral scientist (Beverly Hills) (00027642), 51 (6): 772

Kidd, S. (2008). Resilience in homeless youth: The Key Role of Self-esteem. American Journal of Orthopsychiatry (0002-9432), 78 (2): 163

Kidd, S. A., (2013). Brief report: Youth pathways out of homelessness - Preliminary 
findings. Journal of adolescence (London, England.) (0140-1971), 36(6): 1035 .

Kidd, S. A., \& Davidson, L. (2007). You have to adapt because you have no other choice: The stories of strength and resilience of 208 homeless youth in New York City and Toronto. Journal of Community Psychology, 35(2): 219-238

Kidd, S. A., Karabanow, J., Hughes, J., \& Frederick, T. (2013). Brief Report: Youth Pathways out of Homelessness - Preliminary Findings. Journal of adolescence 36(6): $1035-37$.

Kidd, S. A., (2007). Youth Homelessness and Social Stigma. Journal of youth and adolescence (0047- 2891), 36 (3): 291

Kidd, S.A., (2003). Street Youth: Coping and Interventions. Child and Adolescent Social Work Journal. 20(4): 235-61.

Klodawsky, F., Aubry, T. Nemiroff, A., Bonetta, C. \& Willis, A. (2007). What Happens Over Time: Researching Homelessness Longitudinally. Canadian Journal of Urban Research 16(1): 93-111.

Kufeldt, K., \& Nimmo, M. (1987). Youth on the street. Child Abuse and Neglect, 11(4): 531-543.

Kuhn R., Culhane D. (1998). Applying cluster analysis to test of a typology of homelessness: results from the analysis of administrative data. American Journal of Community Psychology. 17(1): 23 - 43.

Kurtz, P. D., Jarvis, S. V., \& Kurtz, G. L. (1991). Problems of homeless youth. Social Work, 36(4): 309 - 314.

La Gory, M., Fitzpatrick, K., \& Ritchey, F. (2001). Life chances and choices: Assessing quality of life among the homeless. The Sociological Quarterly, 42: 633-651.

Luthar, S. S. (2000). Research on Resilience: Response to Commentaries. Child Development (0009-3920), 71 (3): 573.

Mayock, P,, E, O’Sullivan, and Mary L, (2011). Young People Exiting Homelessness: An Exploration of Process, Meaning and Definition. Housing Studies 26(6): $803-26$.

McClelland, J. L. (1978). Phenomenology of Perception. Science (New York, N.Y.) 201(4359): $899-900$. 
Molina, E. (2000). Informal non-kin networks among homeless Latino and African American men: Form and functions. The American Behavioral Scientist, 43: $663-685$.

Molina-Jackson, E. (2008). Homeless not hopeless. Lanham, MD: University Press of America.

Morrissey, J. P., Calloway, M., Bartko, W. T., Ridgely, M. S., Goldman, H. H., \& Paulson, R. I. (1994). Local mental health authorities and service system change: Evidence from the Robert Wood Johnson Foundation Program on Chronic Mental Illness. The Milbank Quarterly, 49-80.

National Alliance to End Homelessness (2009). Homelessness Looms as Potential Outcome of Recession. Available: http://www.endhomelessness.org/page//files/2161_file_Projected_Increases_in_Homelessness.pdf

National Alliance to End Homelessness (2018). Racial Disparities in Homelessness in The United States. Available: https://endhomelessness.org/resource/racialdisparities-homelessness-united-states

National Association to End Homelessness. (2014). The State of Homelessness in America Available: .http://b.3cdn.net/naeh/d1b106237807ab260f_qam6ydz02.pdf

National Low Income Housing Coalition (2014). Housing Spotlight: The Affordable Rental Housing Gap Persists. Available: http://nlihc.org/sites/default/files/HS_4-1.pdf.

National Law Center on Homelessness \& Poverty (2010). Staying Home: The Rights of Renters Living in Foreclosed Properties. Available: http://nlchp.org/documents/StayingHome.

National Law Center on Homelessness \& Poverty (2015). Homelessness in America: Overview of Data and Causes. Available: https://nlchp.org/wpcontent/uploads/2018/10/Homeless_Stats_Fact_Sheet.pdf

National Law Center on Houselessness \& Poverty (2004). Legal Tools to End Homelessness. Available: http://www.nlchp.org/content/pubs/youth\%20Legal\%20Tools.pdf

Navarro, Z. (2006). In Search of Cultural Interpretation of Power. IDS Bulletin, 37(6): $11-22$

Neale, J,. (1997). Homelessness and Theory Reconsidered. Housing Studies, 12(1): 47 $-61$.

Patton, M. (1987). How to Use Qualitative Methods in Evaluation (Program Evaluation Kit (2nd Edition.). Newbury Park, Calif.: Sage Publications. 
Pescosolido, B.A., \& Rubin, B.A. (2000). The web of group affiliations revisited: Social life, postmodernism, and sociology. American Sociological Review, 65: $52-76$.

Plummer, D. L., Stone, R. T., Powell, L., \& Allison, J. (2016). Patterns of adult crossracial friendships: A context for understanding contemporary race relations. Cultural Diversity and Ethnic Minority Psychology, 22(4): 479-494

Portland Housing Bureau. (2015). The Point-in-Time Count of Homelessness in Portland/ Multnomah County, Oregon. Available: www.portlandoregon.gov/phb/article/532833

U.S. Census Bureau (2019). Quick Facts. Available: https://www.census.gov/quickfacts/fact/table/US/PST045219

Ravitch, D. (2010). The Death of Life of the Great American School System: How Testing and Choice Are Undermining Education. New York: Basic Books

Rollins, C., Glass, N. E., Perrin, N. A., Billhardt, K. A., Clough, A., Barnes, J., Hanson, G. C. \& Bloom, T. L. (2012). Housing instability is as strong a predictor of poor health outcomes as level of danger in an abusive relationship: findings from the SHARE Study. Journal of Interpersonal Violence, 27(4): 623 - 643.

Ray, N. (2006). Lesbian, Gay, Bisexual and Transgender Youth: An Epidemic Of Homelessness. New York: National Gay and Lesbian Task Force Policy Institute And The National Coalition For The Homeless.

Reitzes, D. C., Crimmins, T. J., Yarbrough, J. \& Parker, J. (2011). Social support and social network ties among the homeless in a downtown Atlanta park. Journal of Community Psychology, 39: 274-291

Roschelle, A. R., (2004). Fitting in and Fighting Back: Stigma Management Strategies among Homeless Kids. Symbolic Interaction (0195-6086), 27 (1): 23

Scott, J. \& Marshall, G. (2009). Oxford Dictionary of Sociology. New York: Oxford University Press.

Shelton, K. H., Taylor, P. J., Bonner, A., \& van den Bree, M. (2009). Risk factors for homelessness: Evidence from a population-based study. Psychiatric Services, 60(4): 465-472.

Shields, T. G (2001). Network news construction of homelessness: 1980-1993. The communication review (Yverdon, Switzerland) (1071-4421), 4 (2): 193 
Shinn, M. (2008). Long-Term Associations of Homelessness With Children's WellBeing. The American behavioral scientist (Beverly Hills) (0002-7642), 51 (6): 789.

Simons, R.L., \& Whitbeck, L. B. (1991). Running away during adolescence as a precursor to adult homelessness. Social service review, 65 (2): 224_247.

Stanford Center for the Study of Families, Children, and Youth (1991). The Stanford Studies of Homeless Families, Children, and Youth. Stanford, CA: The Center.

Strauss, A., \& Corbin, J. (1990). Basics of qualitative research: Grounded theory procedures and techniques. Newbury Park, CA: Sage.

Sullivan B. (2002). News release: White House Interagency Council announces new strategy to combat chronic homelessness: new plan will better coordinate federal response to homelessness. Washington, D.C., Interagency Council on Homelessness, July 18, 2002

Broadhead-Fearn, D., \& White, K. M. (2006). The role of self-efficacy in predicting rule-following behaviors in shelters for homeless youth: A test of the theory of planned behavior. The Journal of Social Psychology, 146(3): 307-325.

Thompson, S. J., Ryan, T. N., Montgomery, K. L., Lippman, A. D. P., Bender, K., \& Ferguson, K. (2016). Perceptions of resiliency and coping: Homeless young adults speak out. Youth \& Society, 48(1): 58-76.

Tsemberis, S., Kent Henwood. F. Benjamin, David Hsun-Ta Hsu, Hailey Dent, Winetrobe Adam, Carranza Suzanne Wenzel (2013). Transitioning from Homelessness: A "Fresh-Start". Journal of the Society for Social Work and Research, 4(1): 47 - 57

U.S. Department of Justice - Federal Bureau of Investigation (2016). Uniform Crime Report Hate Crime Statistics. Available: https://ucr.fbi.gov/hatecrime/2016/topic-pages/incidentsandoffenses.pdf

U.S. Department of Housing Urban Development (2019). Houselessness Definition. Available: http://portal.hud.gov/hudportal/documents/huddoc?id=PIH201315HomelessQAs.pdf

U.S. States Conference of Mayors (2014). Hunger and Homelessness Survey: A Status on Hunger and Homeless in America's Cities - A 25-City Survey. Available: http://www.usmayors.org/pressreleases/uploads/2014/1211-reporthh.pdf.

Waquant, L. (2013). Habitus as topic and tool. Reflections on becoming a prizefighter. Sociological Studies, 11(11): 113-120. 
Warren, R. L., Rose, S. M., \& Bergunder, A. F. (1974). The structure of urban reform: Community decision organizations in stability and change. Lexington, MA: Lexington Books.

Washington, P. S. (2011). Homeless youth: a concept analysis. Journal of Community Health Nursing, 28(3): 168-178. 


\section{APPENDIX A}

\section{SAMPLE INTERVIEW GUIDE}

1. What is your race/ethnicity? (Race)

2. What gender do you most identify with? (Gender)

3. How old are you now? (Age)

4. At what age did you first become houseless? (Demographics)

5. How many times have you been homeless?

6. At what age did you transition into conventional housing? (Timeline)

7. How long have you been living in conventional housing

8. Do you live in communal (with roommates) housing or alone

9. What things helped you to survive when you were houseless? (Skills)

10. How did you learn about services that help people survive and exit life on the streets?

11. As you reflect on your experience of houselessness what factors made you decide to seek conventional housing?

12. As you reflect on how you made the transition what factors about yourself or skills you have help you move from a life off the streets? (Resilience)

13. As you think about your experiences what kind of services were most important to your transition off the streets?

14. Based on your experiences, what services do you think would be most helpful for people who transition off the streets? (Needed Services)

15. In your opinion, what attributes/skills do you think a person who has transitioned into conventional housing possess or has? (Resilience)

16. Do you still have contact with people who are houseless? (Social Networks) If so what kind of contact? (Friends) (Financial Support) (Mentors) (Mental Health Support) (Why or why not)

17. Tell me about the people you hang out with now that you are housed? (Social Networks)

18. Do they help you out? (Support)

19. How do you feel know that you have a place to call home? (Feeling)

\section{Demographics}

1. Are you currently married, widowed, divorced, separated, or have you never been married?

2. Do have children?

3. Number of children?

4. What age are you children?

5. Are you currently working?

6. If unemployed what do you do for and income?

7. What is your occupation?

8. How many hours do you work, at all your jobs?

9. What is your approximate personal yearly income?

10. Is there anything else that you wanted to share or add that I did not cover?

11. 11. Do you have any final questions form me about this study?

12. 12. Would you like to receive a copy of the final report? (If so please provide your email)

13. Email address: 


\title{
APPENDIX B INFORMED CONSENT
}

\author{
The Portland State University Consent to Participate in Research \\ The Self-Reported Experiences of Houseless Individuals \\ Who Have Transitioned into Conventional Housing
}

Dear Participant:

You are being asked to take part in this study because you fit the criteria, as being formerly houseless as a youth and returned to conventional housing as an adult. As part of the study, I am interested in your experiences as a formerly houseless individual, who has successfully transitioned from life off the streets. The information I collect will help to understand the pathways, factors, and usage of social service agencies in the process of houseless exits. It will also contribute to new ways to think about how individuals can be supported in their exits. If you decide to participate, you will be asked to share your experiences and perspectives with me in a tape-recorded interview lasting about one hour. The interview will take place at a location of your choice that is comfortable and convenient for you. You will be asked questions about your experiences as a houseless individual, how you were able to move off the streets.

You are not being paid for your participation in this study, but you will be given a gift bag of Nabisco products as compensation for your time. You can stop this study at any time once it has begun, you can skip questions for any reason, and you will still be given a convenience gift regardless of your willingness to participate. While nothing in the interview guide is expected to cause you any discomfort. I will provide you with a list of free counseling centers located in the Portland area should you feel the need to talk to a trained professional. There is no direct benefit to you for your participation. This study will give you a chance to share your experiences and talk about what helped you on your pathway out of houselessness.

Any information that is obtained in connection with this study that can be linked to you or identify you will be kept confidential. Your name will not be used, I will choose an alias, and there will be no readily recognizable features of your life in the thesis or publications. Your participation is completely voluntary. Your decision to participate or not will not affect your relationship with the researcher or with Portland State University in any way.

The Portland State University Institutional Review Board (IRB) that oversees human subject research and/or other entities may be permitted to access your records, and there may be times when we are required by law to share your information. It is the investigator's legal obligation to report child abuse, child neglect, elder abuse, harm to self or others or any lifethreatening situation to the appropriate authorities, and; therefore, your confidentiality will not be maintained.

If you have questions regarding your rights as a research participant, you may call the PSU Office for Research Integrity at (503) 725-2227 or 1(877) 480-4400. The ORI is the office that supports the PSU Institutional Review Board (IRB). The IRB is a group of people from PSU and the community who provide independent oversight of safety and ethical issues related to research involving human participants. For more information, you may also access the IRB website at https://sites.google.com/a/pdx.edu/research/integrity. If you have any questions, or would like to speak to the researcher, please contact Joyce McNair at (503) 314-6636 or jmcnair@pdx.edu

You are making a decision whether to participate in this study. Your signature below indicates that you have read the information provided (or the information was read to you). By signing (marking an $\mathrm{X}$ below) this consent form, you are not waiving any of your legal rights as a research participant. You have had an opportunity to ask questions and all questions have been answered to your satisfaction. By signing this consent form, you agree to participate in this study. A copy of this consent form will be provided to you.

Name/Signature

Date 


\section{APPENDIX C OPENING STATEMENT}

In 1987, I was pregnant with my third son in a bad and violent marriage. One day my husband walked away from us as if we never existed. I was alone, 25 years old and pregnant with my third kid. My ex-husband was in the military and I felt like I could rely on the VA for their help if I needed it. One day the military police knocked at my door searching for him, cause he went A-Wall. I felt as if my whole world was crumbling. Something inside me shook, it was that fight or flight instinct kicking in. I had to keep on, if for no one but my kids. I decided that I was going to make it without him I didn't need the drama.

I started working temporary jobs, found a day-care for my kids. I was able to pay my bills and keep a roof over our heads; but as my belly grew I wondered how I would survive after I had my baby.

I went to see my landlord and told him my situation and asked if I could pay higher rent to catch-up on the months rent I could not pay while I recovered. He told me "No" he said that if I didn't pay my rent, he would evict me. I remember walking back to my apartment thinking, how I am going to have this baby, pack my things in storage and move into my car with my kids. I don't remember taking care of them that night. I don't remember going to work the next day. I just remember is getting to the day-care to pick up my sons and starting to cry. I couldn't stop. Rosie, the woman who owned the daycare, was attempting to calm me down. I tried to hold back the tears but I couldn't I told her that I was gonna be homeless after I had my baby. She told me that I could stay in her back room of the day-care, she was gonna make it a nursery and said my children and I could stay there until I could get on my feet.

I'll never forget that feeling, the day I moved into my apartment. I remember feeling safe, secure, happy, and at that moment, I felt invincible.

This is the reason I am doing this study. I want to know how other people get out of houselessness. I want to know how they did it. I want to know if someone shared my feelings once they got their keys to their new place.

In 1987, there were no programs that assisted houseless individuals that I knew about. I want to know how someone without any assistance could get their own place without help.

When I was houseless, the woman who owned the daycare that my kids went to helped me get on my feet. My relationship with Rosie became stronger than my relationship with my family. I could not have moved into my own place without her help, and I will always be grateful to her. 


\section{Seeking Previously Homeless Individuals for a Research Study}
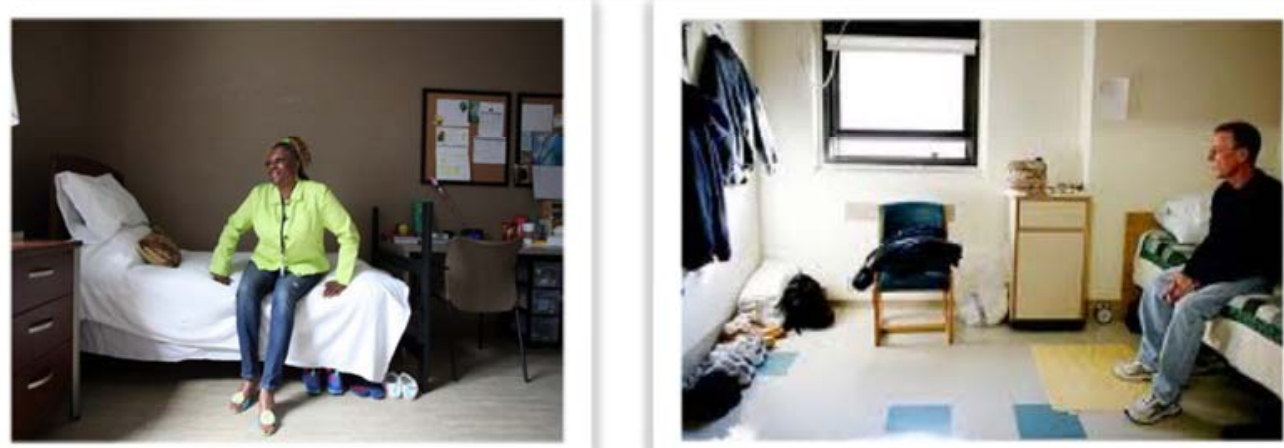

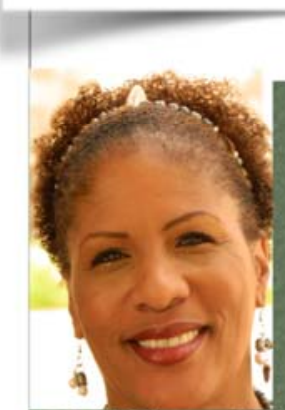

Cell Phone (503) 314-6636 Email:Jmcnair@pdx.edu

Portland State University College of Liberal Arts \& Sciences, Department of Sociology P.O. Box 751 Portland, OR 97207-0751 Office (503) 725-3926
Hello, my name is Joyce McNair and I am a graduate student at Portland State University.

- I have designed a study regarding exits out of homelessness/houselessness and I need volunteers for my study.

- Were you homeless/houseless as a youth and now live in conventional housing?

- I am interested in your experiences and would like to interview you for my research project

- I am seeking a total of (10-15) individuals

- My study explores the pathways taken by adults out of houselessness and your experience with supportive services that aided you.

- Interviews will be audio recorded and last one hour.

- A gift will be provided for your time and convenience 


\section{APPENDIX E \\ FREE OR FEE BASED COUNSELLING SERVICES \\ IN PORTLAND OREGON}

De Paul Treatment Center Inc.

Youth and Family Services

4310 NE Killingworth Street

P.O. Box 3007

Portland, Oregon 97208

Phone: (503) 535-1181

De Paul Treatment Centers Inc

205 East 3rd Avenue

P.O. Box 3007

Portland, Oregon 97208

Phone: (503) 693-3104

Native American Rehabilitation

Association of the Northwest Inc

17645 NW Saint Helens Highway

Portland, Oregon 97231

Phone: (503) 224-1044

Albertina Kerr Centers

722 NE 162nd Ave.

Portland, Oregon 97230

Phone: (503) 255-4205

Cascadia Mental Health

Locations:

3034 NE Dr. MLK, Jr. Blvd.

Portland, Oregon 97212

2415 SE 43rd

Portland, Oregon 97206

10373 NE Hancock St., Suite 200

Portland, Oregon 97220

Emergency Walk-ins Call 503-674-77

The PSU Community Counseling

Clinic

615 SW Harrison

Portland, Oregon 97201

Phone: (503) 725-4620

Phone: (503) 226-3021
Dougy Center

3909 SE 52nd Ave

Portland, Oregon 97206

Phone: (503) 775-5683

Lewis \& Clark Community Counseling

Center

4445 SW Barbur Boulevard

Portland, Oregon 97239

Phone: (503) 768-6320

Northwest Catholic Counseling Center

8383 NE Sandy Blvd. Suite \#205

Portland, Oregon 97220

Phone: (503) 253-0964

Psychological Services Center

511 SW 10th St. Suite \#400

Portland, Oregon 97205

Phone: (503) 352-2400

Quest Center for Integrative Health

2901 E. Burnside

Portland, Oregon 97214

Phone: (503) 323-8203

$\underline{\text { Samaritan Counseling Center }}$

1205 NE Broadway Street

Portland, Oregon 97232

Phone: (503) 281-3318

The Grotto

8840 NE Skidmore

Portland, Oregon 97294

Phone: (503) 261-2425

William Temple House

2023 NW Hoyt St.

Portland, Oregon 97209

Phone: (503) 226-3021

YWCA Counseling Center

1111 SW 10th Ave.

Portland, Oregon 97205

Phone: (503) 294-7400 